\title{
Techno-Economic Analysis of the Oxy-Fuel Combustion Power Cycles with Near-Zero Emissions
}

\author{
Vladimir Kindra ${ }^{1}{ }^{\mathbb{D}}$, Andrey Rogalev ${ }^{1}$, Evgeny Lisin ${ }^{2, *}$, Sergey Osipov ${ }^{1}$ and Olga Zlyvko ${ }^{1}$ \\ 1 Department of Innovative Technologies of High-Tech Industries, National Research University “Moscow \\ Power Engineering Institute", 111250 Moscow, Russia; kindravo@mpei.ru (V.K.); rogalevan@mpei.ru (A.R.); \\ osipovsk@mpei.ru (S.O.); zlyvkoov@mpei.ru (O.Z.) \\ 2 Department of Economics in Power Engineering and Industry, National Research University “Moscow Power \\ Engineering Institute", 111250 Moscow, Russia \\ * Correspondence: lisinym@mpei.ru
}

check for updates

Citation: Kindra, V.; Rogalev, A.; Lisin, E.; Osipov, S.; Zlyvko, O.

Techno-Economic Analysis of the Oxy-Fuel Combustion Power Cycles with Near-Zero Emissions. Energies 2021, 14, 5358. https://doi.org/ $10.3390 /$ en14175358

Academic Editor: Ricardo J. Bessa

Received: 14 July 2021

Accepted: 26 August 2021

Published: 28 August 2021

Publisher's Note: MDPI stays neutral with regard to jurisdictional claims in published maps and institutional affiliations.

Copyright: (c) 2021 by the authors. Licensee MDPI, Basel, Switzerland. This article is an open access article distributed under the terms and conditions of the Creative Commons Attribution (CC BY) license (https:/ / creativecommons.org/licenses/by/ $4.0 /)$.
Abstract: This paper is devoted to improvement of environmental safety in hydrocarbon-firing TPPs. Despite the development of renewable power sources, the number of traditional power production facilities continues its growth. The toxic emission mitigation in traditional TPPs has been deeply investigated, but the problem of greenhouse gas atmospheric emissions is of topical interest. Oxy-fuel technology reduces $\mathrm{CO}_{2}$ emissions and is highly efficient and environmentally safe. Also, it requires relatively low capital investments. Thermal efficiency analysis shows that the Allam cycle facilities have the best efficiency. Their thermodynamic parameters can be optimized with minimal primary costs and capital investments. This newly developed analysis was used to compare the investment efficiency of projects for the buildup of oxy-fuel and combined cycle facilities. Without emission quote payments, the NPV of combined cycle projects is $16 \%$ higher, as well as having a lower DPP. The electricity production primary costs in oxy-fuel and combined cycle facilities are similar, which reflects the technologies' similarity and similar fuel costs. Implementation of carbon dioxide emission quote marketing makes oxy-fuel facilities more investment-attractive. Parametric studies show that when Russia implements $\mathrm{CO}_{2}$ emission quotes compatible with the current EU level, an oxy-fuel facility erection project will be financially reasonable. Thus, it can be concluded that the construction of oxy-fuel power plants is one of the most promising and investment-attractive solutions to reduce $\mathrm{CO} 2$ emissions in the energy sector for large industrialized countries. The managerial consequences of their implementation will include the stabilization of greenhouse gas emissions while ensuring the financial stability of the energy industry.

Keywords: TPP; near-zero emission technologies; oxy-fuel combustion power cycles; carbon dioxide capture; carbon dioxide emission quotes payment; technical and economic assessment

\section{Introduction}

The continuous growth of population and industry is causing a monotonous increase of power consumption that brings with it a few negative environmental effects, the first of which is global warming. Numerous studies and analyses have shown a correlation between organic fuel combustion and climate changes that confirm the global environmental damage from the power industry.

Since the last century, the Mauna-Loa observatory (Hawaii) has been continuously measuring the $\mathrm{CO}_{2}$ atmospheric content. The long-term measurement results show an annual $\mathrm{CO}_{2}$ content increase from 315 to 406 ppm during the period from 1958 to 2019 [1]. In other words, in the last 60 years the $\mathrm{CO}_{2}$ content has grown by about $30 \%$. This rapid $\mathrm{CO}_{2}$ increase is abnormal and is caused by anthropogenic factors [2].

The interest of the world community in the global climate changes resulted in the issue of a few international agreements that required countries to stabilize or reduce the greenhouse gas emissions through improvement of their power industries. Specifically, in 1997 
the Kyoto Protocol and in 2015 the Paris Agreement were signed. An emission mitigation effect may be obtained through agreements between the main industrial countries.

The four world leaders in annual carbon dioxide emissions are China, the USA, India and Russia (Figure 1) [3].

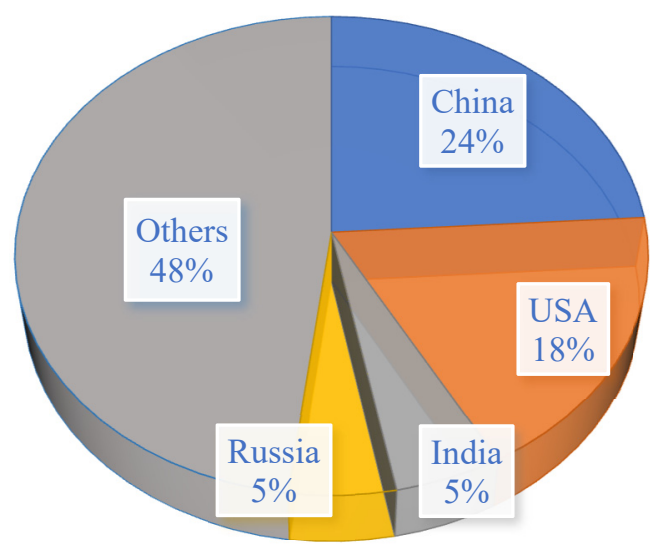

Figure 1. Distribution of carbon dioxide emissions in countries.

The dynamics of this parameter in the main emitter countries allow its approximate forecast for the oncoming decades (Figure 2) [4,5]. Since 1976, the USA and Russia's $\mathrm{CO}_{2}$ emissions have stayed at a constant level. On the other side, in China and India this parameter has increased by a few times, with the maximal rate in the 21 century beginning because of the rapid increase in industrial activity.

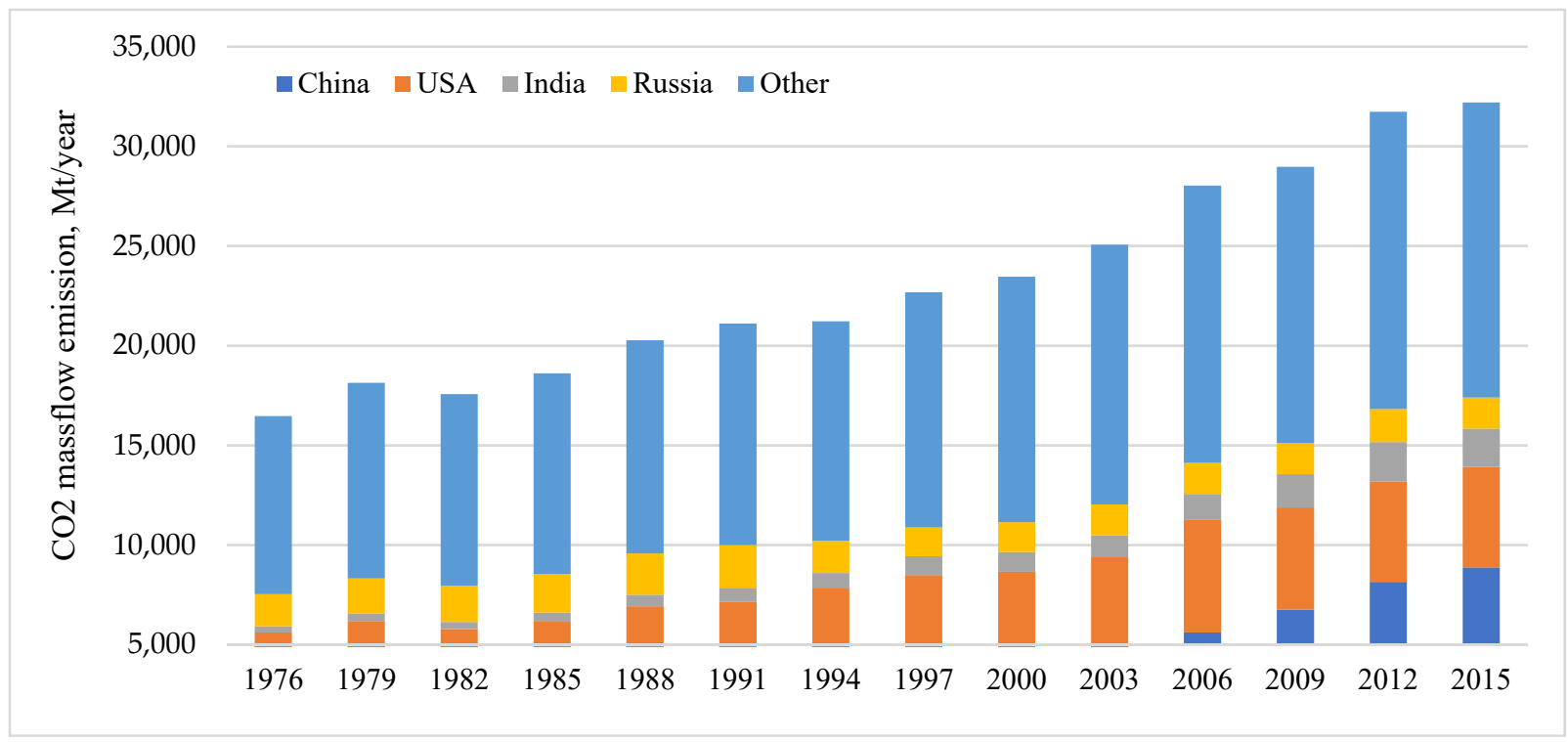

Figure 2. Carbon dioxide emissions by country.

Reduction of or at least retaining the $\mathrm{CO}_{2}$ atmospheric content requires remarkable time and investment for improvement and innovation in industry. Not all the main $\mathrm{CO}_{2}$ emitting countries supported the last climate agreement, and in 2020 the USA completed their exit from the Paris Agreement. On the other side, Russia expressed completed approval of the Paris Agreement conditions in September 2019. The low interest in this agreement by the countries with highly developed industries is due to financial reasons.

In the countries mentioned above, about $75 \%$ of the anthropogenic $\mathrm{CO}_{2}$ emissions are produced by TPP combustion of oil, natural gas and coal $[6,7]$. The source of this remarkable contribution of the power industry to $\mathrm{CO}_{2}$ emissions is the wide application of 
Rankine and Brayton-Rankine cycles in power plants, where the heat supply is provided by the combustion of hydrocarbon fuels in the air.

Great effort has been directed towards the development of renewable energy sources (RESs), but in the large industrial countries the main power sources are still traditional TPPs, and their number constantly grows [1]. The main reason for this effect is the complicated power control in RESs and the expensive electrical energy accumulation.

Thus, the main point in the environmental safety of advanced industrial countries should be the reduction of the emissions produced in organic fuel burning TPPs. Mitigation of the emission of toxic agents, such as nitrogen and sulfur oxides, ash, etc., is understood in detail [2,8-12] and the technology has been successfully applied in traditional TPPs, but the search for directions for greenhouse gas mitigation is critically important. This study is intended to fill the above gap.

\section{Approaches to Reducing $\mathrm{CO}_{2}$ Emissions in the Fossil Fuel TPP}

The $\mathrm{CO}_{2}$ emissions in traditional TPPs can be reduced with a few methods, each of them having advantages and shortages specific to the application countries related to their technology and financial levels.

The first method is based on the improvement of efficiency in available organic fuel-burning power plants. The plant efficiency depends upon numerous factors, but first of all upon the equipment efficiency and the fuel price. Specifically, in Russia, the municipal heat supply is a large part of the annual supply schedule, so it is reasonable to develop maneuverable co-generation plants that supply heat and electricity from a single cycle $[13,14]$. On the contrary, in the USA and China, the heat demand is lower and the fuel prices are higher than the Russian ones. Thus, there is a demand for high-efficiency power blocks that produce only electricity and combined cycle facilities and steam turbine blocks with supercritical and ultra-supercritical steam parameters [15].

The traditional method for steam turbine and combined cycle technology improvement is an increase of the steam initial pressure and temperature. Thermodynamically, this is the main method possible for the improvement of TPP efficiency. The initial steam temperature provides the main influence on the TPP efficiency, and a $1 \%$ increase improves the TPP mean efficiency by $0.13 \%[14,16,17]$.

The plots in Figure 3 depict the subsequent efficiency improvements in coal-firing TPPs in countries with advanced power industries [14,16]. In the countries with organic fuel deficits, the effective power production methods are being developed more quickly.

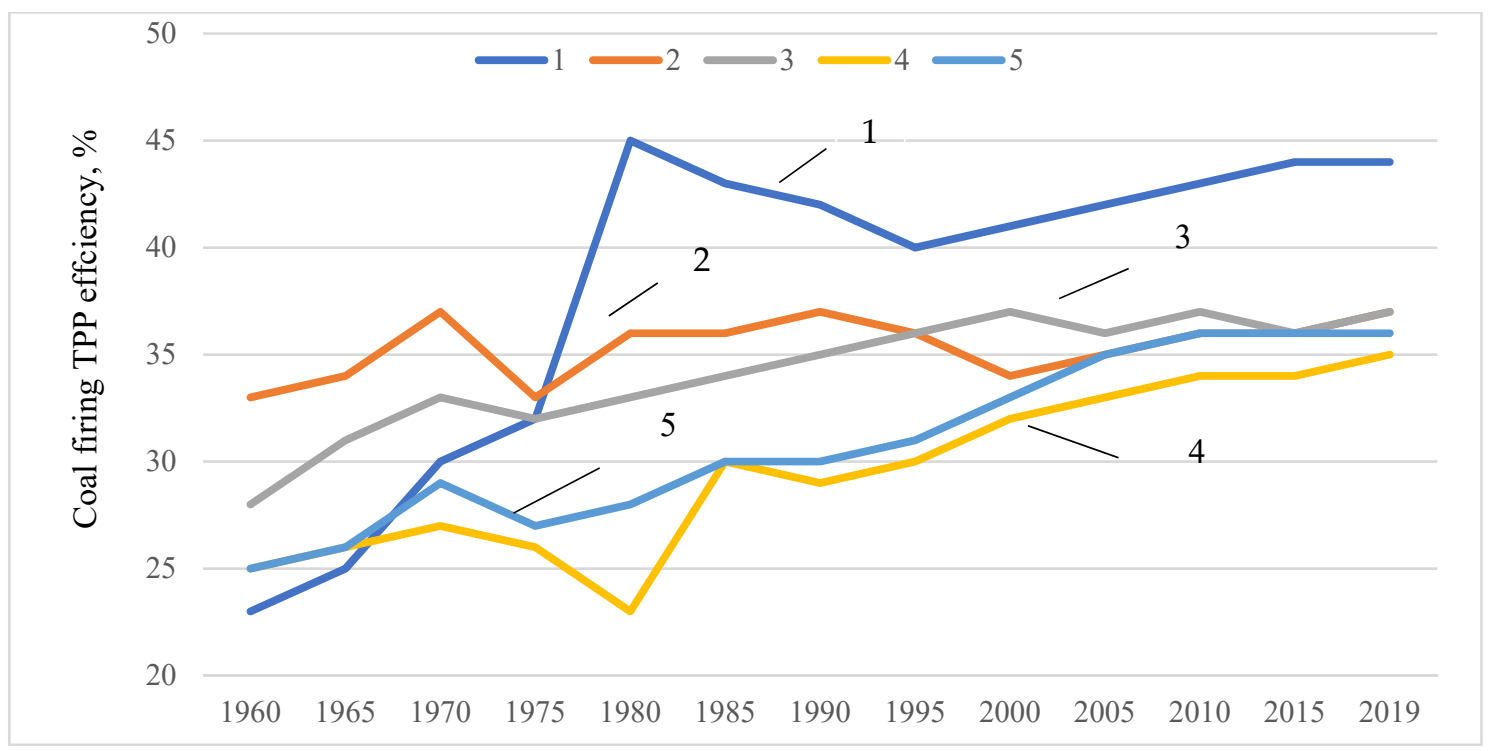

Figure 3. Coal-based power production in the countries with advanced power industries: 1-Japan, 2-USA, 3-Germany, 4-China, 5-Russia. 
In coal-firing TPPs a $1 \%$ efficiency improvement reduces the $\mathrm{CO}_{2}$ mean emissions by 3\% (Figure 4) [18,19].

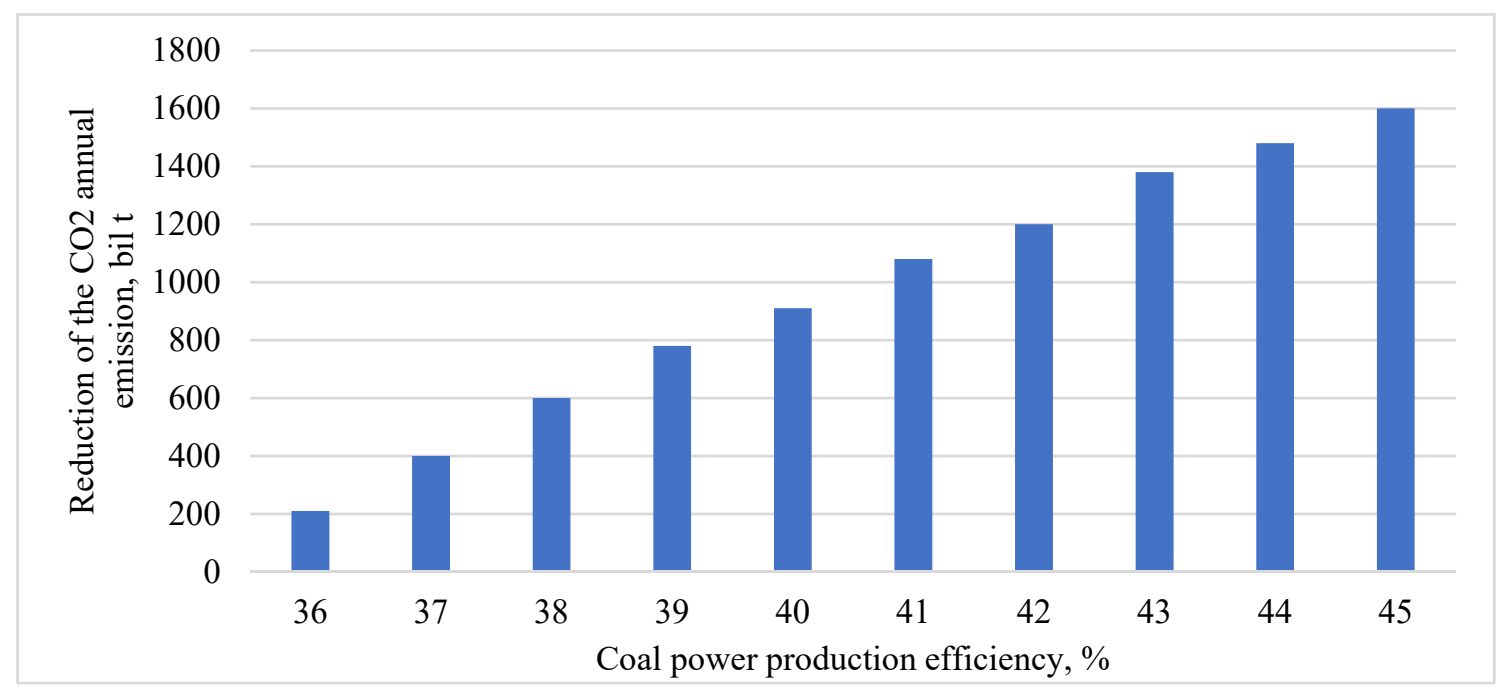

Figure 4. Relation of $\mathrm{CO}_{2}$ emission reductions and coal-firing TPP efficiency.

Despite the advantages of SC facility efficiency, many countries continue construction of subcritical steam TPPs, which can be explained by their higher financial efficiency in small power production facilities. Furthermore, the fuel quality subsequently becomes worse, and its preparation needs additional power consumption. Thus, it will be quite a problem to mitigate the $\mathrm{CO}_{2}$ atmospheric content only through the improvement of TPP efficiency when combined with the subsequent power production increase.

Another method is based on the sequestering technology that is used in traditional organic fuel combustion power production cycles. This technology includes $\mathrm{CO}_{2}$ capture, its compression to the supercritical state, pipeline transportation and storage [20-22].

The most common $\mathrm{CO}_{2}$ storage geology formations are oil reservoirs and unmined coal layers [23,24]. Usually, the $\mathrm{CO}_{2}$ is stored at depths below $800 \mathrm{~m}$ where the ambient temperature and pressure transform carbon dioxide into its liquid form.

Table 1 shows the remarkable capacities of potential reservoirs for $\mathrm{CO}_{2}$ storage. If all the $\mathrm{CO}_{2}$ emissions in TPPs are captured, the capacity of the oil and gas layers will be sufficient for 350 to 470 years [24,25].

Table 1. Geological storage options for $\mathrm{CO}_{2}$ emissions.

\begin{tabular}{cccc}
\hline Reservoir Type & $\mathrm{CO}_{2}$ Storage Minimal Capacity, & CO2 Storage Maximal Capacity, \\
\hline Oil and gas fields & Gt & 675 & 900 \\
\hline Coal beds with no industrial use & $3-15$ & 200 \\
\hline Deep-location coal beds & 1000 & - \\
\hline
\end{tabular}

The regions with good prospects for the carbon dioxide storage are in Russia, the USA, China and India, which have large demands for new power production facilities. The sequestering technology intended for $\mathrm{CO}_{2}$ emission mitigation will therefore be essential in the coming decades.

Currently, there are three main $\mathrm{CO}_{2}$ capture technologies that have reached the level of industrial use (Figure 5) [26-29]. 


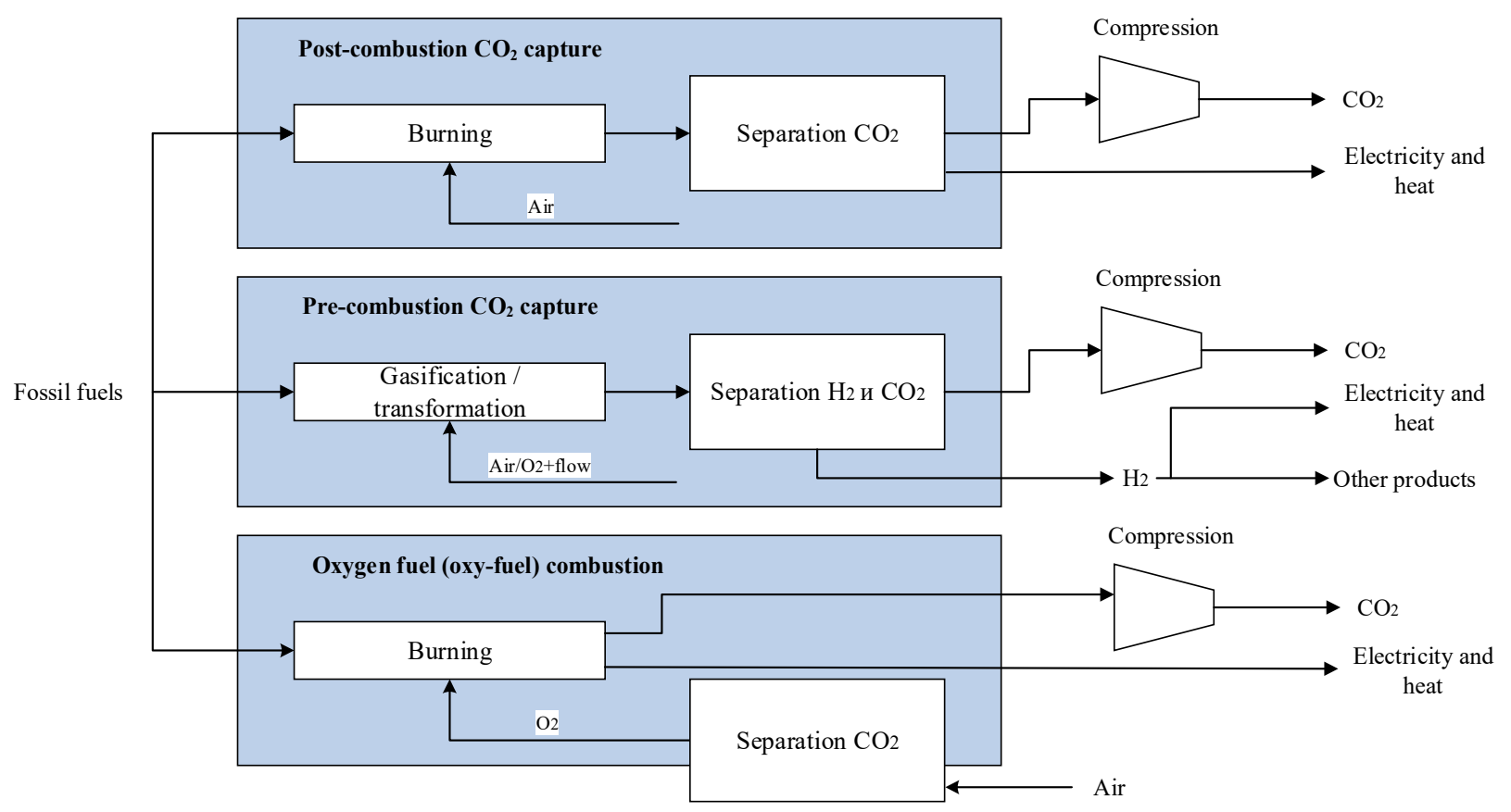

Figure 5. Schematic image of the $\mathrm{CO}_{2}$ capture systems.

The first technology is post-combustion $\mathrm{CO}_{2}$ capture from flue gas with chemical agents like amine or ammonia.

The second technology involves pre-combustion $\mathrm{CO}_{2}$ capture from the solid fuel gasification process. The gasification result is synthetic fuel gas which mostly consists of carbon monoxide $\mathrm{CO}$ and hydrogen $\mathrm{H}_{2}$. $\mathrm{CO}$ is transformed to $\mathrm{CO}_{2}$ with water vapor, after which $\mathrm{CO}_{2}$ is removed by a sorbent.

The third technology involves oxygen fuel (oxy-fuel) combustion where the oxidizer is pure oxygen. The combustion product is a gas mixture enriched with carbon dioxide. After the water vapor is removed by condensation, the mixture is ready for sequestration.

Oxy-fuel combustion is a prospective technology for $\mathrm{CO}_{2}$ emission reduction because of its high effectiveness, environmental safety and low capital investments for the construction of environmentally safe facilities. Currently, the introduction of this technology is mostly limited by financial factors. Insofar as harmful emissions are being limited and the greenhouse gas quotes trade is being developed, oxy-fuel power production technology may become remarkably attractive.

\section{Principal Heat Flow Schemes of Oxy-Fuel Combustion Thermodynamic Cycles}

The semi-closed oxy-fuel combustion cycle power production facilities consist of the cycle core, the oxygen production facilities and the carbon dioxide storage preparation.

The first oxy-fuel cycle versions appeared at the end of the previous century. Now, "green" power production technology is actively subsidized, and legislation for carbon dioxide emission reduction has been formed so that the power industry corporations build experimental facilities. This forms the prerequisites for the construction of organic fuel power facilities with "zero" harmful emissions [30,31].

In the oxy-fuel cycle the combustion chamber is supplied with three flows, which are the gas fuel flow - possibly the syngas produced by coal gasification - the oxygen flow and the carbon dioxide, which limits the combustion chamber temperature. The combustion reaction product flow is a mixture of carbon dioxide and water vapor at temperatures of 1000 to $1700^{\circ} \mathrm{C}$. It enters a cooled gas turbine (GT), expands and then enters a surface heat exchanger (HE), which may be a heat recovery boiler or a regenerator. The flow releases most of its heat and enters the cooler-separator (CS), where it cools down and its water vapor is condensed and removed from the cycle flow. After this the flow is rich with carbon 
dioxide and it enters the compressor (C), its pressure grows, and it is sent to the combustion chamber recirculation. Thus, the thermodynamic cycle is closed [32,33]. The flow mass balance is closed by the removal of partly working fluid for its storage.

Figure 6 shows an oxy-fuel power production complex flow diagram.

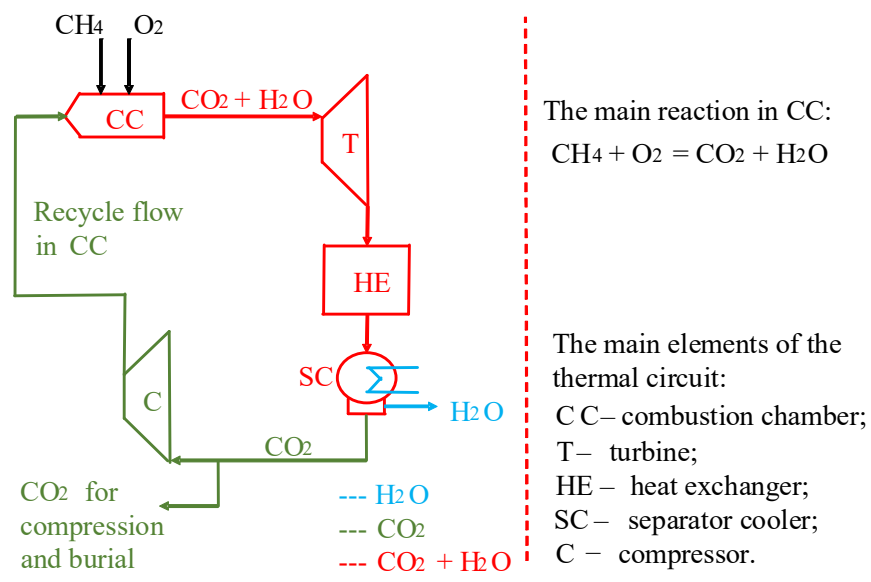

Figure 6. Schematic diagram of the oxy-fuel energy complex.

The following semi-closed oxy-fuel cycles are widely known:

- Semi-closed oxygen combustion cycle (SCOC-CC);

- MATIANT cycles;

- Graz cycles;

- Water or CES cycles;

- Allam or NET power cycles [34-38].

The cycles listed above have almost zero emissions of harmful gases. The oxy-fuel technology allows sequestering of up to $99 \%$ of the $\mathrm{CO}_{2}$ produced by organic fuel combustion in oxygen. Different oxy-fuel cycles have different efficiencies and specific capital investments.

The semi-closed oxygen combustion cycle has the smallest power production efficiency. This cycle is a Brayton-Rankine combined cycle with oxy-fuel oxidation and dioxide recirculation (Figure 7). At the working fluid turbine inlet temperature of $1300{ }^{\circ} \mathrm{C}$, this cycle's energy supply efficiency is below $45 \%[35,39]$.

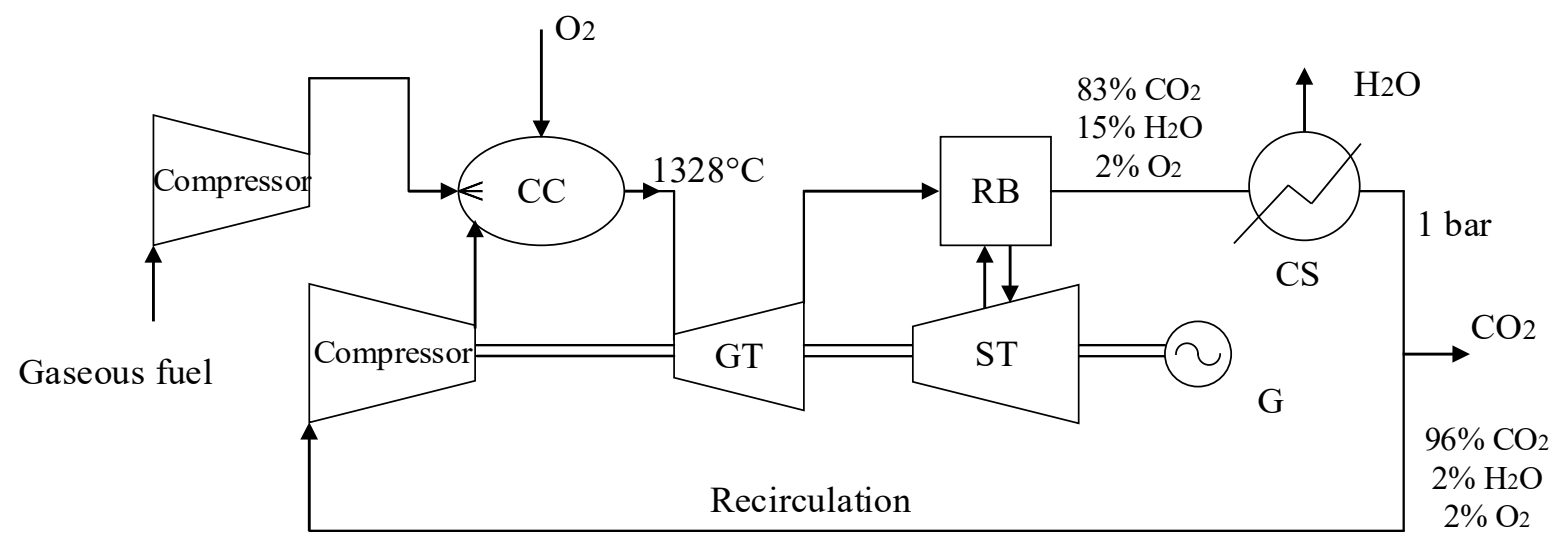

Figure 7. Semi-closed SCOC-CC cycle flow diagram.

In this cycle the gas fuel and high-purity oxygen mixture is supplied into the combustion chamber (CC) at the stoichiometric ratio. The combustion flame temperature of this mixture may be up to $3500{ }^{\circ} \mathrm{C}$, so the combustion chamber is supplied with a third flow with a high $\mathrm{CO}_{2}$ content that limits the maximal combustor temperature. The produced gas 
flow has $-80 \% \mathrm{CO}_{2}$ content at $1300-1400{ }^{\circ} \mathrm{C}$. The flow is supplied to the gas turbine (GT) that drives the electricity generator $(\mathrm{G})$. In the gas turbine the flow expands and enters the recovery boiler (RB). The recovery boiler produces superheated steam through utilization of the gas turbine exhaust heat. The steam drives the steam turbine (ST) electricity generator. The boiler exit flue gas is supplied to the cooler-separator (CS), where a large part of water is separated by its condensation at nearly atmospheric pressure. Then, a part of the carbon dioxide flow leaves the cycle circuit for its further sequestering. The remaining flow mostly consists of carbon dioxide. It enters the compressor and re-circulates.

Another technology is the MATIANT cycle developed in 1997 by its inventors Matiew and Yantovsky $[36,40,41]$. This cycle's specific feature is the expansion of a mixture with high $\mathrm{CO}_{2}$ content in high, intermediate and low-pressure turbines (Figure 8).

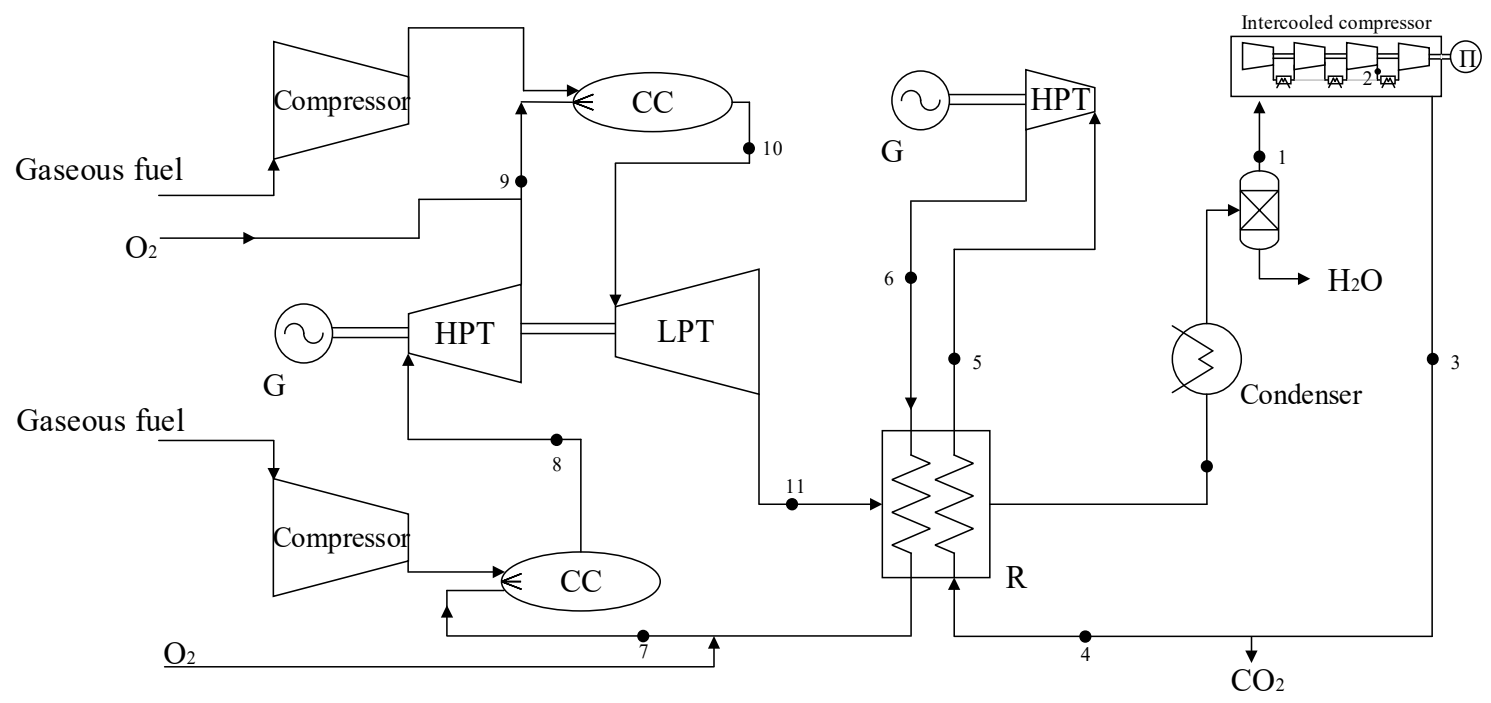

Figure 8. MATIANT cycle flow diagram.

The multi-stage inter-cooled compressor compresses carbon dioxide with up to $300 \mathrm{bar}$ pressure and supplies it to the regenerator $(\mathrm{R})$. The flow takes some heat from the LPT exit flow. The heated flow enters the HPT where it expands down to 40 bar and returns to the regenerator for secondary heating. The regenerator exit flow enters the cooled combustion chamber (CC), where the fuel combustion in an oxygen environment heats the flow up to $1300{ }^{\circ} \mathrm{C}$. Then, the hot combustion products expand in the cooled HPT and enter the second CC, which is also supplied with fuel and oxygen. The CC exit flow enters the cooled LPT where it expands down to about atmospheric pressure. The hot carbon dioxide LPT exit flow is the regenerator hot environment. The regenerator exit flow is sent to the condenser where it is cooled by the heat transfer to ambient atmospheric pressure. Furthermore, in the condenser, water is condensed and separated.

The idea of the Graz cycle (Figure 9) belongs to Herbert Jericha, who presented the concept in $1985[38,42,43]$. The cycle can operate with practically any organic fuel.

The Graz cycle consists of high- and low-temperature parts. The high temperature part is a Brayton cycle with compressors $\mathrm{C} 1, \mathrm{C} 2, \mathrm{C} 3$, a combustion chamber (CC) and a high-temperature turbine (HTT). The low-temperature part is a Rankine cycle with a low-pressure turbine (LPT), a condenser, a heat recovery steam generator (HRSG) and a high-pressure turbine (HPT) [42].

The stoichiometric mixture of fuel and oxygen is supplied to the combustion chamber at 40 bar. The water vapor and carbon dioxide flow also enter the CC to cool its internal space and burners. The $1400{ }^{\circ} \mathrm{C}$ hot mixture consists of three quarters carbon dioxide and one quarter steam. It enters the HTT and expands there down to 1 bar and $642{ }^{\circ} \mathrm{C}$. The HTT exhaust is sent to the HRSG, which produces and superheats the steam supplied to the HPT. Then, the gas mixture enters the LPT at $160^{\circ} \mathrm{C}$, expands down to $0.25 \mathrm{bar}$ and 
enters the condenser. At the condenser cooling-water temperature of $20^{\circ} \mathrm{C}$, pressure of 0.25 bar and water vapor content of $31 \%, 93 \%$ of the water vapor is condensed. As a result it is possible to efficiently separate the carbon dioxide from the condenser.

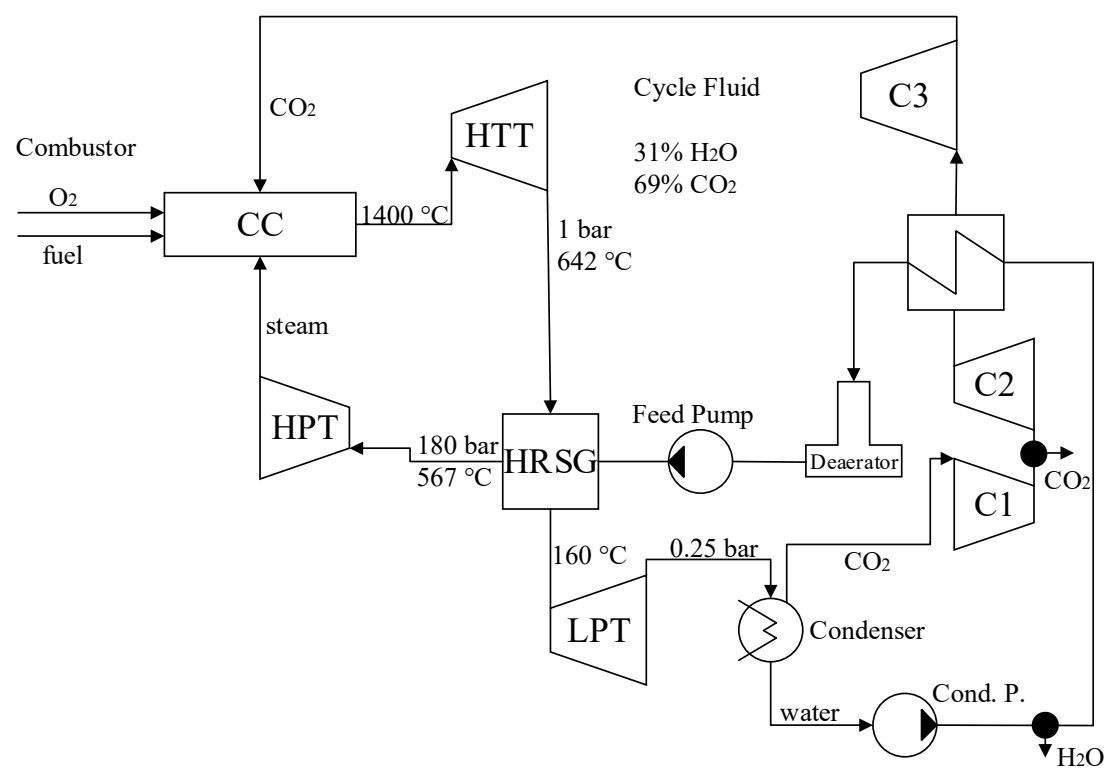

Figure 9. Flow diagram of the Graz basic cycle.

The condenser exit water subsequently passes the condensate pump, cooler and deaerator (D) and the feedwater pump. Then, it is sent to the HRSG, where it is evaporated and super-heated by cooling of the HTT exit gas mixture. The generated superheated steam is supplied to the HPT at 180 bar and $567^{\circ} \mathrm{C}$. The steam expanded in the HTT is supplied for the cooling of burners at the first and second HTT stages. The condenser exit carbon dioxide enters the compressor $\mathrm{C} 1$ where it is compressed up to 1 bar. Some carbon dioxide is sent for sequestering and the remaining part is sent to the $\mathrm{CC}$ where it cools the CC inner surface.

The Graz cycle concept has a few merits. In this cycle, heat is applied at a rather high temperature, as is typical in gas turbines. The expansion process is completed at rather low pressure, as is typical in steam turbines. This combination allows the cycle to be thermodynamically highly efficient.

The cycle working fluid is a two-component mixture of carbon dioxide and water. This mixture is used for the whole range of temperatures, and this is the main source of the low power consumption for compression. One more positive effect is the possibility of cooling the first and second HTT stages with the HPT exit steam, which has the proper temperature and pressure.

Like many other oxy-fuel cycles, the water or CES cycle was developed at the end of the 20th century. Its concept was presented by the inventors of Clean Energy Systems in 1998 [37,44]. Figure 10 presents a simplified water cycle flow diagram.

A large part of the fuel is burned in the high pressure combustion chamber at 80 to 100 bar. The HPT inlet flow temperature is below $760^{\circ} \mathrm{C}$, which is provided by the injection of water into the combustion chamber flowpath. The working fluid expands in the HPT to $40 \mathrm{bar}$ and is sent to the reheater $(\mathrm{RH})$ to increase its temperature up to $1760^{\circ} \mathrm{C}$. The $\mathrm{RH}$ exit flow is sent to the intermediate pressure turbine (IPT). The IPT is cooled by a part of the HPT exit flow that bypasses the reheater. After the working fluid works in the IPT, the fluid has a pressure of $1 \mathrm{bar}$ and a temperature of $760^{\circ} \mathrm{C}$. Then, it is sent to the LPT where it finally expands to the pressure provided by the condenser. In the condenser the fluid is condensed and the carbon dioxide is separated. Then, the flow is further compressed and stored. 


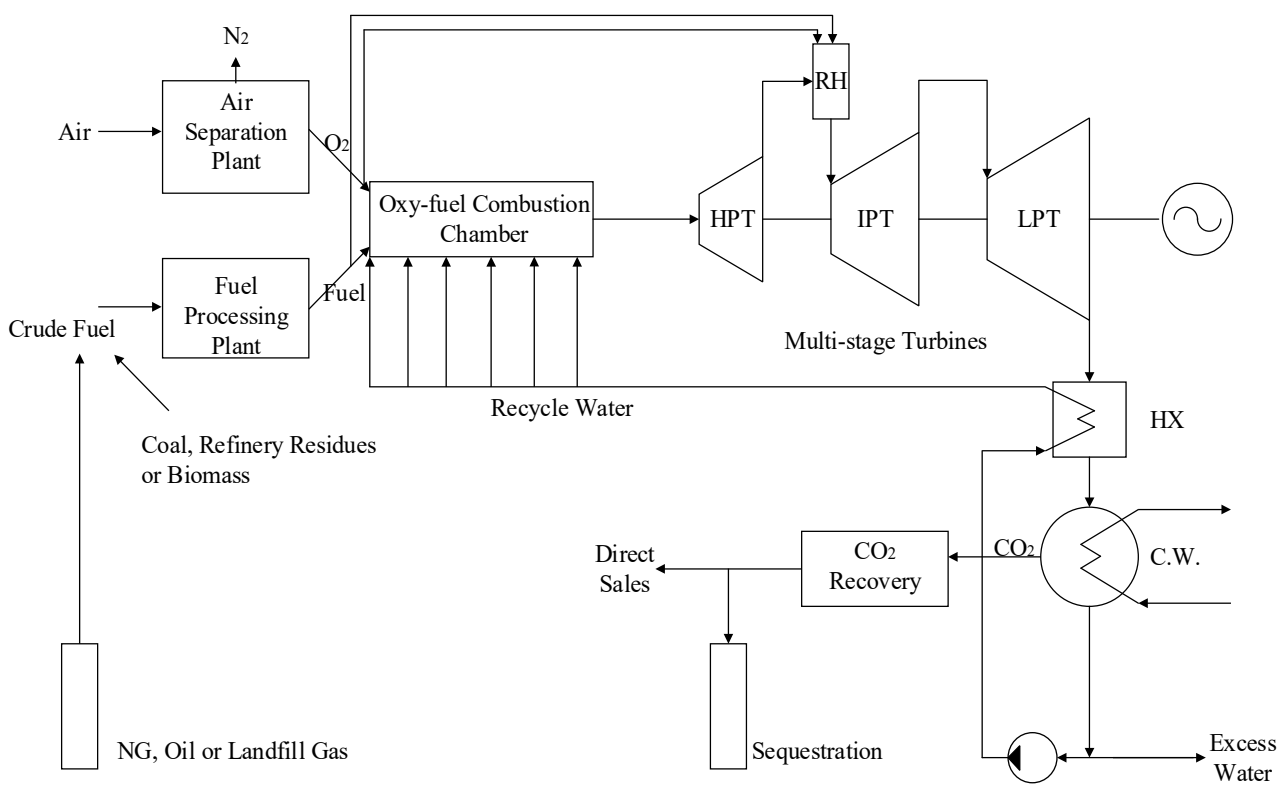

Figure 10. CES cycle concept flow diagram.

Different authors give different and contradictory assessments of the efficiency of the CES cycle. The authors of [45] give the CES cycle an efficiency of $44.6 \%$.

The Allam cycle (Figure 11) is the most efficient among the oxy-fuel cycles. Its net power supply efficiency is 55 to $59 \%$ for natural gas operations. This is $11 \%$ higher than the efficiency of the combined cycle with carbon dioxide capture from flue gas [46]. Such extreme efficiency can be reached in the semi-closed supercritical carbon dioxide cycle through the optimization of its parameters.

Gaseous fuel

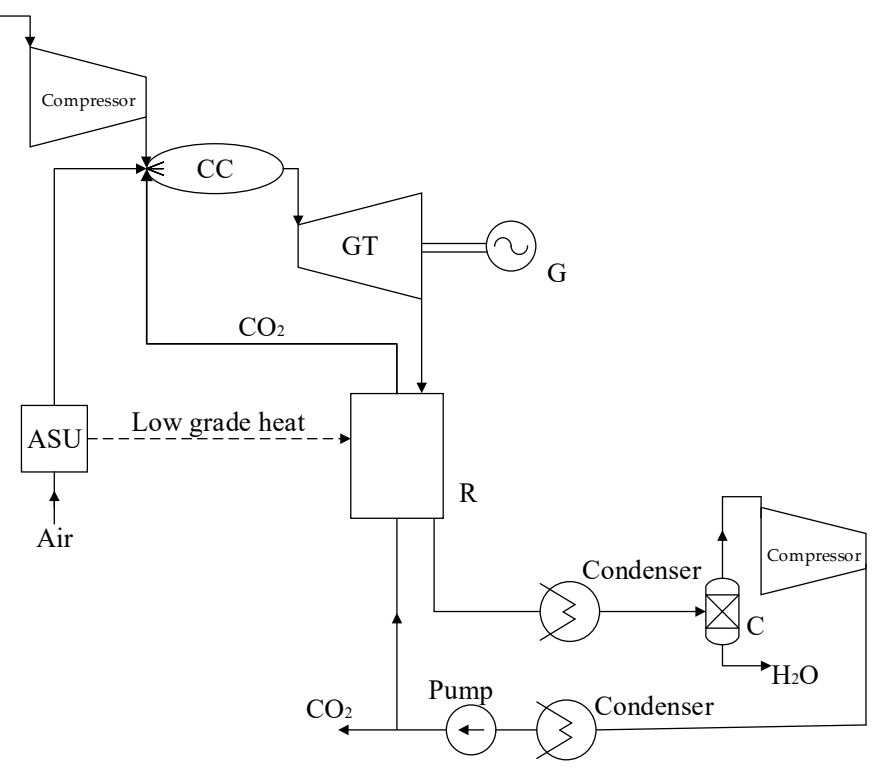

Figure 11. Allam cycle concept flow diagram.

The compressor compresses the working fluid near the carbon dioxide phase change border. Under this condition, the carbon dioxide is practically incompressible, so the power spent for its compression is minimal. The intermediate coolers of the multi-stage compressor also reduce the compression work. The practically incompressible fluid pressure is finally increased before it enters the high temperature regenerator $(\mathrm{R})$; the increase is produced by a pump. The high minimal pressure of the cycle of about 30 bar enables 
comparatively low energy expenditure for the compression of excessive carbon dioxide before its storage. The low-potential heat produced in the oxygen production in the air separation unit (ASU) is supplied to the regenerator to heat the $\mathrm{CO}_{2}$ flow from 100 to $400{ }^{\circ} \mathrm{C}$, which also improves the cycle efficiency.

Table 2 compares the financial, technical and environmental performance of oxyfuel technology against the performance of traditional combined cycle facilities with and without carbon dioxide capture $[16,47,48]$.

Table 2. Oxy-fuel cycle performances compared against those of combined cycles.

\begin{tabular}{|c|c|c|c|c|c|c|c|}
\hline $\begin{array}{l}\text { Oxy-Fuel } \\
\text { Combustion } \\
\text { Cycles }\end{array}$ & Fuel & Oxidizer & $\begin{array}{c}\text { Net } \\
\text { Efficiency, \% }\end{array}$ & $\begin{array}{c}\text { Specific } \\
\text { Amount of } \\
\text { Produced } \mathrm{CO}_{2} \\
\text { g/kWh }\end{array}$ & $\begin{array}{c}\mathrm{CO}_{2} \text { Capture } \\
\text { Rate, } \%\end{array}$ & $\begin{array}{c}\text { Specific } \\
\text { Amount of } \\
\text { Captured } \mathrm{CO}_{2} \\
\text { g/kWh }\end{array}$ & $\begin{array}{c}\text { Specific } \\
\text { Amount of } \mathrm{CO}_{2} \\
\text { Emitted to the } \\
\text { Atmosphere, } \\
\text { g/kWh }\end{array}$ \\
\hline \multicolumn{8}{|c|}{ Oxy-fuel combustion cycle } \\
\hline SCOC-CC & $\mathrm{CH}_{4}$ & $\mathrm{O}_{2}$ & 45 & 406 & 98.9 & 402 & 5 \\
\hline MATIANT & $\mathrm{CH}_{4}$ & $\mathrm{O}_{2}$ & 46 & 421 & 98.9 & 417 & 5 \\
\hline S-Graz cycle & $\mathrm{CH}_{4}$ & $\mathrm{O}_{2}$ & 54 & 359 & 98.9 & 355 & 4 \\
\hline CES cycle & $\mathrm{CH}_{4}$ & $\mathrm{O}_{2}$ & 48 & 404 & 98.9 & 399 & 4 \\
\hline Allam cycle & $\mathrm{CH}_{4}$ & $\mathrm{O}_{2}$ & 57 & 343 & 98.9 & 339 & 4 \\
\hline \multicolumn{8}{|c|}{ Combined steam-gas cycle } \\
\hline $\begin{array}{l}\text { Combined } \\
\text { cycle-gas } \\
\text { turbine } \\
\text { with CCS }\end{array}$ & $\mathrm{CH}_{4}$ & Air & 48 & 404 & 89 & 359 & 44 \\
\hline $\begin{array}{l}\text { Combined } \\
\text { cycle-gas } \\
\text { turbine } \\
\text { without CCS }\end{array}$ & $\mathrm{CH}_{4}$ & Air & 60 & 323 & 0 & 0 & 323 \\
\hline
\end{tabular}

As can be seen from the table, oxy-fuel cycles, compared to combined steam-gas cycles, have significant environmental advantages (expressed in particular in the reduction of greenhouse gas emissions), with comparable values in the efficiencies of their power units. The Allam cycle is the most the efficient and environmentally safe. Its net efficiency is above $55 \%$ and the atmospheric emissions only of $4 \mathrm{~g} / \mathrm{kWh}$.

This study's goal is to study the financial feasibility of the transition of traditional TPPs to environmentally safe technology. First, it is reasonable to consider the design and introduction of oxy-fuel facilities based on the most efficient cycle, which is the Allam cycle. These facilities' performance is remarkably influenced by the combination of thermodynamic parameters.

\section{Influence of Thermodynamic Parameters of Oxy-Fuel Combustion Power Facilities on Their Financial and Economic Efficiency}

Nowadays, oxygen fuel combustion is mainly limited by financial factors. Toughening the restriction regulations on harmful emissions and the development of the greenhouse emission quotes trade may make oxy-fuel electricity production remarkably attractive.

Despite the importance of environmental safety, power production technology is usually determined by power production companies that intend to increase profits. Thus, the wide introduction of oxy-fuel power facilities can be implemented only with the achievement of attractive financial performances in the construction of prospective power plants. The financial efficiency criteria may be the net present value and the discounted payback period. 
Power facility financial efficiency depends on the thermodynamic parameters that influence the power production efficiency, harmful atmospheric emissions and the plant equipment price. Oxygen combustion of natural gas does not produce nitrogen or sulfur oxides. If we assume a constant $\mathrm{CO}_{2}$ capture rate, the determining factors of a facility's financial performance can be summarized as the following:

1. The facility net efficiency, which influences the fuel consumption and the $\mathrm{CO}_{2}$ emission;

2. The kilowatt price of the installed power;

3. The lifetime of the main equipment;

4. The schedule for the operation of the installed power;

5. The prices of fuel and electricity supplied by the grid;

6. $\mathrm{CO}_{2}$ emission quotas.

The first three items depend on the thermodynamic parameters of the facility.

Studies $[16,31,48]$ have shown that the cycle's initial temperature and pressure and the turbine exit pressure have the primary influence upon the facility net efficiency. A temperature change in the working fluid of $10^{\circ} \mathrm{C}$ in the range from 1100 to $1500{ }^{\circ} \mathrm{C}$ or an initial pressure change in the range from 25 to $35 \mathrm{MPa}$ cause a net efficiency change of $0.15 \%$. A final pressure change of $0.1 \mathrm{MPa}$ causes a mean change in net efficiency of $0.07 \%$.

The thermodynamic parameters influence the price of the installed power of the production equipment. An increase of the initial temperature increases the consumption of the heat resistance alloys in the manufacture of the main equipment, carbon dioxide turbine, combustion chamber and regenerator.

Investigations show that a $10 \%$ increase of working fluid massflow causes a $7 \%$ turbine price increase, a 15\% combustion chamber price increase and a 5\% recuperator price increase. A $10 \%$ increase of the cycle initial temperature causes an $84 \%$ turbine price increase, a $12 \%$ combustion chamber price increase and a 15\% recuperator price increase. A $10 \%$ increase of the cycle initial pressure causes a $13 \%$ turbine price increase, a $10 \%$ combustion chamber price increase and an $11 \%$ recuperator price increase. A $10 \%$ increase of the turbine exit pressure reduces the turbine price by $9 \%$. Therefore, the thermodynamic parameters mostly influence the carbon dioxide turbine price.

Figure 12 shows relations between the main oxy-fuel facility equipment and the thermodynamic parameters of a facility as the equipment price percentage. The calculation basepoint is the following set of thermodynamic parameters:

- Carbon monoxide turbine inlet working fluid massflow: $600 \mathrm{~kg} / \mathrm{s}$;

- Initial temperature: $1100{ }^{\circ} \mathrm{C}$;

- Initial pressure: $30 \mathrm{MPa}$;

- Carbon dioxide turbine exhaust pressure: $3 \mathrm{MPa}$.

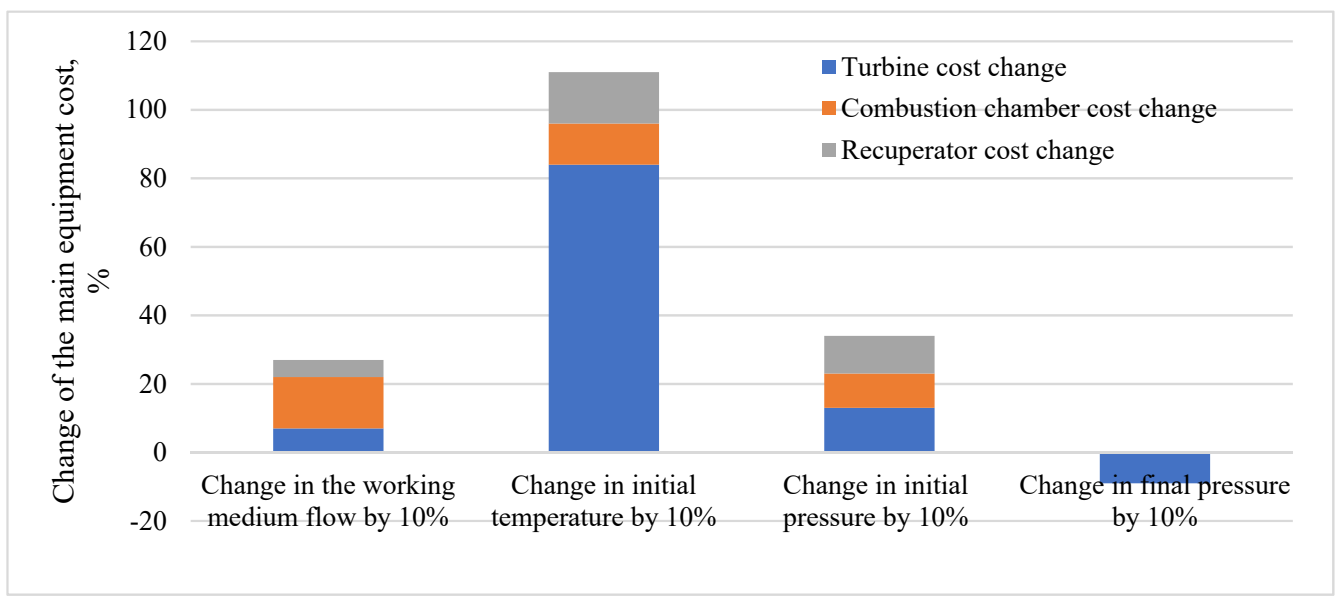

Figure 12. Influence of key thermodynamic parameters on the oxy-fuel facility equipment price. 
A facility's thermodynamic parameters influence its financial performance in opposite directions, so a construction investment project needs financial feasibility optimization including and excluding the emission quotes.

\section{Method for the Financial Feasibility Study of Oxy-Fuel Power Facilities Construction}

The financial feasibility study of a power production facility construction project consists of a comparative analysis of financial performances for different technical parameters of the produced electricity and allows the optimization of the production technology and the equipment content from the point of view of maximal financial efficiency.

The cycle initial temperature, initial pressure and exhaust pressure exert the main influences on the financial performance of oxy-fuel facilities. These parameters can be verified in wide ranges, so application of the access scan optimization method is not reasonable. On the other hand, an approved combination of key thermodynamic parameters can reasonably reduce the amount of calculations and makes it possible to obtain a set of parameters that provide the maximal financial efficiency.

The oxy-fuel cycle initial temperature can be verified from 1100 to $1500{ }^{\circ} \mathrm{C}$. This parameter can be considered at limiting and mean values of 1100,1300 and $1500{ }^{\circ} \mathrm{C}$. The initial pressure may be verified from 25 to $35 \mathrm{MPa}$, and the values to be considered are 25, 30 and $35 \mathrm{MPa}$. In a similar way, the carbon dioxide turbine exhaust pressure limits and consideration values are 2, 3, 4 and $5 \mathrm{MPa}$. This set of parameters allows the formation of 36 combinations of the facility parameters.

Computer simulation allows the selection of the six main datasets that have the best thermal efficiency and equipment price.

Oxy-fuel power facilities have maximal thermal efficiency with the following sets of thermodynamic parameters:

- Initial temperature: $1300{ }^{\circ} \mathrm{C}$, initial pressure: $25 \mathrm{MPa}$, turbine exhaust pressure: $5 \mathrm{MPa}$, net efficiency: $58.2 \%$

- Initial temperature: $1500{ }^{\circ} \mathrm{C}$, initial pressure: $30 \mathrm{MPa}$, turbine exhaust pressure: $2 \mathrm{MPa}$, net efficiency: $58.2 \%$

- Initial temperature: $1500{ }^{\circ} \mathrm{C}$, initial pressure: $35 \mathrm{MPa}$, turbine exhaust pressure: $2 \mathrm{MPa}$, net efficiency: $58.2 \%$.

The installed power specific price reaches its minimal values with the following parameters:

- Initial temperature: $1100^{\circ} \mathrm{C}$, initial pressure: $25 \mathrm{MPa}$, turbine exhaust pressure: $2 \mathrm{MPa}$, installed power specific price: 32,368.4 RUB/kW;

- Initial temperature: $1100^{\circ} \mathrm{C}$, initial pressure: $30 \mathrm{MPa}$, turbine exhaust pressure: $3 \mathrm{MPa}$, installed power specific price: $34,399.8 \mathrm{RUB} / \mathrm{kW}$;

- Initial temperature: $1100^{\circ} \mathrm{C}$, initial pressure: $35 \mathrm{MPa}$, turbine exhaust pressure: $2 \mathrm{MPa}$, installed power specific price: 36,532.8 RUB/kW.

The technical and financial facility performances with these parameters are compared with the combined cycle ones in Table 3 . The combined cycle facility performances are comparable with those of oxy-fuel, but the latter has much better environmental performance. The calculations were carried out in the Thermaflow software package, and a description of the parametric optimization technique is presented in [35].

The main parts of the capital investment for oxy-fuel facility buildup are the construction work and the recuperator price $[48,49]$. When the initial temperature is increased from 1100 to $1500{ }^{\circ} \mathrm{C}$, the turbine price increases considerably.

An important factor in the financial performance of oxy-fuel facilities is the rate of quotes for toxic and greenhouse gas emissions. In Russia the criteria for TPP environmental purity is the condition that harmful emissions content is kept below the acceptability limits (Table 4) $[16,50,51]$. 
Table 3. Technical and financial performances of oxy-fuel power facilities against those of combined cycle facilities.

\begin{tabular}{|c|c|c|c|c|c|c|c|}
\hline Parameter Sets & 1 & 2 & 3 & 4 & 5 & 6 & \\
\hline \begin{tabular}{ll} 
& \multicolumn{1}{c}{ Facility performance: } \\
- & Working fluid massflow, $\mathrm{kg} / \mathrm{s} ;$ \\
- & Initial temperature, ${ }^{\circ} \mathrm{C} ;$ \\
- & Initial pressure, MPa; \\
Exhaust pressure, MPa.
\end{tabular} & $\begin{array}{c}800 \\
1100 \\
25 \\
2\end{array}$ & $\begin{array}{c}800 \\
1300 \\
25 \\
5\end{array}$ & $\begin{array}{c}800 \\
1100 \\
30 \\
3\end{array}$ & $\begin{array}{c}800 \\
1500 \\
30 \\
2\end{array}$ & $\begin{array}{c}800 \\
1100 \\
35 \\
2\end{array}$ & $\begin{array}{c}800 \\
1500 \\
35 \\
2\end{array}$ & $\begin{array}{l}\text { Combined } \\
\text { Cycle Power } \\
\text { Facility }\end{array}$ \\
\hline Net efficiency, \% & 51.3 & 58.2 & 52.0 & 58.2 & 50.9 & 58.3 & 58.2 \\
\hline Net power, MW & 283.4 & 241.5 & 270.2 & 414.2 & 315.4 & 435.6 & 420.0 \\
\hline Natural gas massflow, $\mathrm{kg} / \mathrm{s}$ & 11.195 & 8.423 & 10.550 & 14.438 & 12.575 & 15.164 & 14.68 \\
\hline $\mathrm{CO}_{2}$ emission massflow, $\mathrm{kg} / \mathrm{s}$ & 0.347 & 0.261 & 0.327 & 0.44671 & 0.389 & 0.469 & 37.683 \\
\hline Gas turbine price, bil. RUB & 478.9 & 555.5 & 393.6 & 1563.4 & 669.3 & 1876.0 & - \\
\hline Compressor price, bil. RUB & 220.1 & 61.5 & 185.9 & 97.9 & 316.9 & 120.2 & - \\
\hline Combustion chamber price, bil. RUB & 609.5 & 739.9 & 706.4 & 999.8 & 842.2 & 1153.0 & - \\
\hline Recuperator price, bil. RUB & 1388.5 & 1904.8 & 1520.0 & 2488.3 & 1866.8 & 3010.9 & - \\
\hline Air split unit price, RUB & 721.3 & 542.7 & 679.7 & 930.2 & 810.2 & 977.0 & - \\
\hline Auxiliary equipment price, bil. RUB & 697.1 & 697.1 & 697.1 & 697.1 & 697.1 & 697.1 & - \\
\hline Total equipment price, bil. RUB & 4115.4 & 4501.5 & 4182.7 & 6776.7 & 5184.4 & 7834.3 & - \\
\hline Installed power specific price, bil. RUB & $32,368.4$ & $41,427.0$ & $34,399.8$ & $36,354.0$ & $36,532.8$ & $39,967.1$ & $35,238.1$ \\
\hline Capital investment, bil. RUB & 9145.3 & $10,003.2$ & 9294.9 & $15,059.4$ & $11,521.0$ & $17,409.5$ & $14,800.0$ \\
\hline
\end{tabular}

Table 4. Limits of harmful atmospheric contents.

\begin{tabular}{ccccc}
\hline Harm Class & Agent & Harmfulness Class & Point limit $\mathbf{K}_{\mathbf{p}}, \mathbf{m g} / \mathbf{m}^{\mathbf{3}}$ & Dayly Mean Content $\mathbf{K}_{\mathbf{c c}}, \mathbf{m g} / \mathbf{m}^{\mathbf{3}}$ \\
\hline 1 & Carbon monoxide & 4 & 5 & 3 \\
\hline 2 & Nitrogen dioxide & 2 & 0.2 & 0.04 \\
\hline 3 & Nitrogen oxide & 3 & 0.4 & 0.06 \\
\hline 4 & Supfur dioxide & 3 & 0.5 & 0.05 \\
\hline 5 & Ammonia & 4 & 0.2 & 0.04 \\
\hline 6 & Hydrogen sulphide & 2 & 0.008 & - \\
\hline
\end{tabular}

The existing Russian emission regulation system is rather mild, and it does not stimulate the development and introduction of new environmentally pure technology.

Buildup of global-level market relations for environmental pollution sales may introduce the financial rationality of environmentally safe technology [16]. This includes emission limits within state borders. The emission permissions are split between the power production companies. A company may either follow the emission regulations through investments into environmentally safe technology or purchase permissions for additional limits if the investment policy seems too expensive. The additional emission amounts may be purchased from the companies for which it is profitable to reduce their emissions below the regulated limits.

In 2010, for the first time, Russia passed quotes for harmful and greenhouse gas emissions to foreign companies. The Japanese companies Mitsubishi and Nippon Oil purchased from the Gasprom Neft company quotes for 290 thousand tons of greenhouse gas emissions. The emission price was evaluated as a total of EUR 3.3 billion. The quotes' transition was undertaken under cooperative execution projects (CEPs) with the technology described in the Kyoto Protocol. The Kyoto Protocol charges the advanced- and transitioneconomy countries with reducing or stabilizing greenhouse emissions. As the result of the implementation of CEPs, Russian companies can receive foreign investments into efficient technology. Harmful emissions are cut down and the project members can sell the emission reduction units $[16,52,53]$. 
Table 5 and Figure 13 demonstrate the analysis method for the comparative financial efficiency of power plant construction in terms of the discounted income, including carbon dioxide emission quotes payment.

Table 5. Analysis method for the comparative financial efficiency of power plant construction, including carbon dioxide emission quotes payment.

\begin{tabular}{|c|c|c|}
\hline Financial Parameter & Calculation Model & Model Parameters \\
\hline Net present value $(N P V)$ & $N P V=\sum_{t=0}^{T} \frac{C F_{t}}{(1+E)^{t}}$ & $\begin{array}{l}C F_{t} \text {-net payment flow in the year } t ; \\
T \text {-period of project implementation; } \\
E \text { - discount rate }\end{array}$ \\
\hline Net payment flow $\left(C F_{t}\right)$ & $C F_{t}=C_{D}+N P_{t}$ & $\begin{array}{l}C_{D} \text {-depreciation payment; } N P_{t} \text {-net } \\
\text { profit in the year } t\end{array}$ \\
\hline Depreciation payment $\left(C_{D}\right)$ & $C_{D}=\frac{C I}{T_{s}}$ & $\begin{array}{l}T_{\mathrm{s}} \text { - equipment operation life; } \mathrm{CI} \text {-facility } \\
\text { construction capital investments }\end{array}$ \\
\hline Net profit $\left(N P_{t}\right)$ & $N P_{t}=P_{t}\left(1-V_{t}\right)$ & $\begin{array}{l}P_{t} \text {-income before tax payment in year } t \\
V_{t} \text {-income tax in the year } t\end{array}$ \\
\hline Income before tax payment $\left(P_{t}\right)$ & $P_{t}=R_{t}-O C_{t}$ & $\begin{array}{c}R_{t} \text {-income from electricity and power } \\
\text { sales in the year } t ; O C_{t} \text {-operation costs } \\
\text { in the year } t\end{array}$ \\
\hline $\begin{array}{l}\text { Income from electricity and power sale } \\
\qquad\left(R_{t}\right)\end{array}$ & $R_{t}=R_{t}^{E}+R_{t}^{C}$ & $\begin{array}{c}R_{t}^{E} \text {-income from electricity sales; } \\
R_{t}^{C} \text {-income from power sales }\end{array}$ \\
\hline Income from electricity sale $\left(R^{E} t\right)$ & $R_{t}^{E}=S^{E} \cdot n \cdot P^{E}$ & $\begin{array}{l}S^{E} \text { —annual electricity supply by a single } \\
\text { power unit; } n \text {-number of power units; } \\
\quad P^{E} \text { —electricity market price }\end{array}$ \\
\hline Income from power sale $\left(R_{t}^{C}\right)$ & $R_{t}^{C}=N \cdot n \cdot P^{C}$ & $\begin{array}{l}N \text { - single power unit net capacity; } \\
P^{C} \text { —capacity market price }\end{array}$ \\
\hline Operation expenses $\left(O C_{t}\right)$ & $\begin{aligned} O C_{t}= & C_{F}+C_{D}+C_{R}+C_{W}+ \\
& C_{\text {other }}+C_{C_{2}}\end{aligned}$ & $\begin{array}{c}C_{F} \text {-fuel expenses; } C_{D} \text {-depreciation } \\
\text { charges; } C_{R} \text {-repair expenses; } C_{W} \text {-wage } \\
\text { expenses; } C_{\text {other }} \text { - overall expenses; } \\
C_{\mathrm{CO} 2} \text { - expenses related to the quote } \\
\text { payment for carbon dioxide emissions }\end{array}$ \\
\hline Fuel expenses $\left(C_{F}\right)$ & $C_{F}=\frac{N \cdot P_{F}}{E F_{n e t} \cdot Q_{L} \cdot 36 \cdot h_{C} \cdot n \cdot(1+\alpha)}$ & $\begin{array}{c}E F_{n e t}-\text { net efficiency; } Q_{L}-\text { low calorific } \\
\text { value; } h_{C} \text {-number of hours of installed } \\
\text { power operation per year; } \alpha \text {-fuel } \\
\text { transportation losses; } P_{F} \text {-fuel price } \\
\text { (natural gas) }\end{array}$ \\
\hline Repair expenses $\left(C_{R}\right)$ & $C_{R}=\beta_{R} \cdot C I$ & $B_{R}$-repair fund allocation \\
\hline Wage expenses $\left(C_{W}\right)$ & $\begin{array}{c}C_{W}=\left(n_{i p} \cdot n \cdot W_{i p}+n_{m p} \cdot W_{m p}\right) \\
(1+\gamma) \cdot 12\end{array}$ & $\begin{array}{l}n_{\mathrm{ip}}, n_{\mathrm{mp}} \text { - strength of management and } \\
\text { operation personnel; } W_{i p}, W_{m p}-\text { mean } \\
\text { monthly management and operation } \\
\text { personnel salary; } \gamma \text {-social allocations }\end{array}$ \\
\hline Overall expenses $\left(C_{\text {other }}\right)$ & $C_{\text {other }}=\mu \cdot\left(C_{R}+C_{D}+C_{W}\right)$ & $\begin{array}{c}\mu \text {-rate of overall expenses for } \\
\text { depreciation, repair and salary payments }\end{array}$ \\
\hline Quote payment for $\mathrm{CO}_{2}$ emissions $\left(\mathrm{C}_{\mathrm{CO} 2}\right)$ & $C_{\mathrm{CO}_{2}}=P_{\mathrm{CO}_{2}} \cdot m_{\mathrm{CO}_{2}}$ & $\begin{array}{c}P_{\mathrm{CO} 2} \text { - price of } 1 \mathrm{~kg} \text { of carbon dioxide } \\
\text { emissions; } m_{\mathrm{CO} 2} \text { - carbon dioxide } \\
\text { emission massflow }\end{array}$ \\
\hline
\end{tabular}




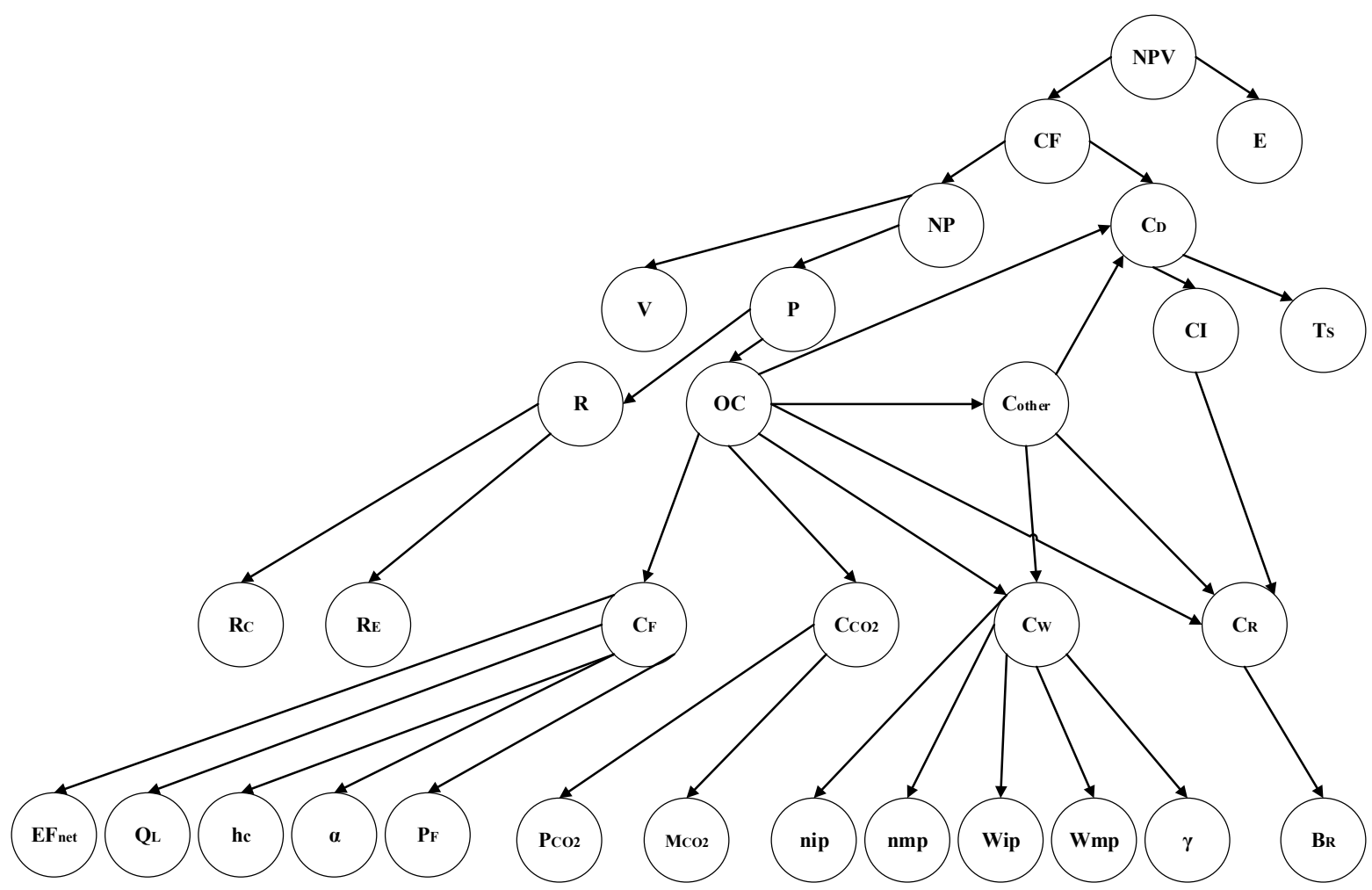

Figure 13. Analysis method diagram of the comparative financial efficiency of power plant construction, including carbon dioxide emission quotes payment.

In accordance with Figure 13, the method was based on the calculation of the net present value (NPV), which consisted of the net payment flow $\left(C F_{t}\right)$ reduced to the initial project time, taking into account the discount rate $(E)$. The payment flows were formed from the net profit $\left(N P_{t}\right)$ from the operation of the power unit and the depreciation payment $\left(C_{D}\right)$. Depreciation payments were calculated based on the data on the facility construction capital investments $(C I)$ and the equipment operation life $\left(T_{S}\right)$. Net profit included income before tax payments $\left(P_{t}\right)$ with less income tax at the rate $\left(V_{t}\right)$. Income before tax payment $\left(P_{t}\right)$ was formed as the difference between the income from the electricity and power sales $\left(R_{t}\right)$ and the operation costs $\left(O C_{t}\right)$. Accordingly, the income $\left(R_{t}\right)$ was partitioned into the income from the sale of electricity $\left(R^{E}{ }_{t}\right)$ and of capacity $\left(R^{C}{ }_{t}\right)$. Income from electricity sales $\left(R_{t}^{E}\right)$ was calculated based on the annual electricity supply by power unit $\left(S^{E}\right)$ and the electricity market price $\left(P^{E}\right)$. Income from power sales $\left(R^{C} t\right)$ was determined by the power unit net capacity $(N)$ and the capacity market price $\left(P^{C}\right)$. The main components of the operation costs $\left(O C_{t}\right)$ were fuel costs $\left(C_{F}\right)$, depreciation charges $\left(C_{D}\right)$, power equipment repair expenses $\left(C_{R}\right)$, wage expenses $\left(C_{W}\right)$, costs associated with quotas for carbon dioxide emissions $\left(C_{\mathrm{CO} 2}\right)$ and other expenses $\left(C_{\text {other }}\right)$. Fuel costs $\left(C_{F}\right)$ were determined based on the net efficiency $\left(E F_{n e t}\right)$ of the power unit, low calorific value $\left(Q_{L}\right)$, number of hours of installed power operation per year $\left(h_{C}\right)$, fuel transportation losses $(\alpha)$ and fuel price $\left(P_{F}\right)$. Repair costs $\left(C_{R}\right)$ were calculated based on the facility construction capital investments $(C I)$ and the repair fund allocation $\left(B_{R}\right)$. Wage costs $\left(C_{W}\right)$ were determined based on data on the strength of operation and management personnel $\left(n_{i p}, n_{m p}\right)$ and their average monthly salaries $\left(W_{i p}, W_{m p}\right)$. The quote payment for $\mathrm{CO}_{2}$ emissions $\left(C_{\mathrm{CO} 2}\right)$ was calculated based on the price of $1 \mathrm{~kg}$ of carbon dioxide emissions $\left(\mathrm{P}_{\mathrm{CO} 2}\right)$ and the massflow of carbon dioxide $\left(m_{\mathrm{CO} 2}\right)$ emitted into the atmosphere. Other expenses $\left(C_{\text {other }}\right)$ were formed as a share $(\mu)$ of the amount of depreciation, repair and salary payments.

A distinctive feature of the proposed method is the possibility, during the feasibility study of a project for the construction of an oxy-fuel power plant, of optimizing its main 
technological characteristics while ensuring a balance between its net efficiency and the specific cost of the installed capacity in the presence of carbon dioxide emission quotes.

\section{Oxy-Fuel Facility Financial Efficiency with Different Thermodynamic Parameters Excluding and Including $\mathrm{CO}_{2}$ Emission Quotas}

Oxy-fuel facilities reach high environmental performances when they operate with the basic part of the electric load schedule. This is facilitated by the high thermodynamic efficiency, large unit power over $1000 \mathrm{MW}$ and low maneuverability, first caused by the multi-flow regenerator operation. So, assessment of the financial efficiency of oxy-fuel facilities can assume a $6000 \mathrm{~h}$ period of installed power use, including possible repair periods. With these assumptions, the mean equipment life is about 200,000 hours. Tables 3 and 6 summarize other input data for this calculation. The data correspond to the practice of financial efficiency assessment of new power industry facility constructions in the Russian Federation.

Table 6. Analysis input data for the financial efficiency of oxy-fuel facilities.

\begin{tabular}{|c|c|c|}
\hline Parameter & Parameter Value & Units \\
\hline Analysis period $\left(T=T_{S}\right)$ & 23 & year \\
\hline Annual inflation & 4 & $\%$ \\
\hline Discount norm $(E)$ & 14 & $\%$ \\
\hline $\operatorname{VAT}\left(V_{t}\right)$ & 20 & $\%$ \\
\hline Number of power facility blocks $(n)$ & 1 & Pcs \\
\hline Wholesale electricity price $\left(P^{E}\right)$ & 1147 & th. RUB/MW hr \\
\hline $\begin{array}{l}\text { Power price under the power availability } \\
\text { agreement in first } 10 \text { years of operation }\left(P^{E}\right)\end{array}$ & 1000 & th. RUB/MW hr \\
\hline Power price in the competitive power market $\left(P^{E}\right)$ & 282,310 & th. RUB/MW hr \\
\hline Natural gas fuel price & 6.48 & rubles $/ \mathrm{kg}$ \\
\hline Natural gas calorific value $\left(Q_{L}\right)$ & 49,157 & $\mathrm{MJ} / \mathrm{kg}$ \\
\hline Repair fund allocation $\left(B_{R}\right)$ & 0.07 & - \\
\hline Operational personnel number $\left(n_{\mathrm{ip}}\right)$ & 140 & person \\
\hline Management personnel number $\left(n_{\mathrm{mp}}\right)$ & 40 & person \\
\hline Operational personnel mean salary & 50 & th. RUB/person \\
\hline Management personnel salary & 90 & th. RUB/person \\
\hline Part for social payments $(\gamma)$ & 0.3 & - \\
\hline Part for overall expenses $(\mu)$ & 0.2 & - \\
\hline
\end{tabular}

Table 7 shows the analysis of the prime cost of electricity production by oxy-fuel facilities with the thermodynamic parameters shown in Table 3. The analysis shows that the prime cost of supplied electricity in an oxy-fuel facility is comparable with similar installed power in a combined cycle facility. The minimal prime cost is reached at the maximal net efficiency values of 58.2 and $58.3 \%$ for thermodynamic parameter sets (4) and (6).

Table 8 presents an analysis of the net present value and discounted payback period. The oxy-fuel facility with thermodynamic parameter set (4) shows the best financial performance. This facility provides a minimal electricity prime cost of $0.84 \mathrm{RUB} / \mathrm{kWh}$ at the installed power price of 36.354 thousand RUB/ $\mathrm{kW}$ together with high integral financial efficiency. 
Table 7. Prime cost of electricity production with best parameters in oxy-fuel facilities and combined cycle ones.

\begin{tabular}{ccc}
\hline Facility Type & Net Efficiency, $\mathbf{~}$ & Electricity Prime Cost, RUB/kWh \\
\hline Oxy-fuel facility with parameter set (1) & 51.3 & 0.949 \\
\hline Oxy-fuel facility with parameter set (2) & 58.2 & 0.838 \\
\hline Oxy-fuel facility with parameter set (3) & 52.0 & 0.938 \\
\hline Oxy-fuel facility with parameter set (4) & $\mathbf{5 8 . 2}$ & $\mathbf{0 . 8 3 7}$ \\
\hline Oxy-fuel facility with parameter set (5) & 50.9 & 0.958 \\
\hline Oxy-fuel facility with parameter set (6) & $\mathbf{5 8 . 3}$ & $\mathbf{0 . 8 3 7}$ \\
\hline Combined cycle facility & $\mathbf{5 8 . 2}$ & $\mathbf{0 . 8 4 0}$ \\
\hline
\end{tabular}

Table 8. Comparative financial efficiency analysis of oxy-fuel and combined cycle facilities.

\begin{tabular}{ccc}
\hline Power Facility Type & NPV, Thousand RUB & DPP, Years \\
\hline Oxy-fuel facility with parameter set (1) & $3,114,534$ & 7 \\
\hline Oxy-fuel facility with parameter set (2) & $2,051,322$ & 8 \\
\hline Oxy-fuel facility with parameter set (3) & $2,169,977$ & 8 \\
\hline Oxy-fuel facility with parameter set (4) & $\mathbf{4 , 4 2 0 , 1 8 2}$ & $\mathbf{8}$ \\
\hline Oxy-fuel facility with parameter set (5) & $1,483,996$ & 9 \\
\hline Oxy-fuel facility with parameter set (6) & $2,401,397$ & 9 \\
\hline Combined cycle facility & $5,148,783$ & 7 \\
\hline
\end{tabular}

If the greenhouse gas emission quotes are not considered, the best oxy-fuel facilities are not as good as the combined cycle ones with an NPV of $16.47 \%$ lower. This may be explained by combined cycles' lower capital investment, lower repair expenses, lower depreciation payment and lower overall expenses for similar powers and efficiencies.

As mentioned above, the key advantage of the oxy-fuel cycle is its near-zero greenhouse emissions. Therefore, implementation in Russia of the $\mathrm{CO}_{2}$ quotes market would remarkably increase the competitive efficiency of oxy-fuel construction projects. In this case, the operation of combined cycle facilities would be combined with the emission quotes purchase, but the oxy-fuel facilities would principally have very low emissions.

Table 9 compares the project financial efficiency of the construction of oxy-fuel and combined cycle facilities, including the differential quote payment for greenhouse gas emissions.

Table 9. Parametric study of financial efficiency of oxy-fuel (4) and combined cycle facilities with different values of $\mathrm{CO}_{2}$ emission quote prices.

\begin{tabular}{|c|c|c|c|c|c|c|}
\hline \multirow[b]{2}{*}{$\begin{array}{l}\text { Emission } \\
\text { Quote Price, } \\
\text { RUB/t } \mathrm{CO}_{2}\end{array}$} & \multicolumn{3}{|c|}{ Oxy-Fuel Facility with Parameter Set (4) } & \multicolumn{3}{|c|}{ Combined Cycle } \\
\hline & $\begin{array}{c}\text { NPV, Million } \\
\text { RUB }\end{array}$ & $\begin{array}{l}\text { DPP, } \\
\text { Years }\end{array}$ & $\begin{array}{c}\text { Cost of } \\
\text { Electricity, } \\
\text { RUB/kWh }\end{array}$ & $\begin{array}{l}\text { NPV, Million } \\
\text { RUB }\end{array}$ & $\begin{array}{l}\text { DPP, } \\
\text { Years }\end{array}$ & $\begin{array}{l}\text { Cost of } \\
\text { Electricity, } \\
\text { RUB/kWh }\end{array}$ \\
\hline 0 & 4.420 & 8 & 0.838 & 5.149 & 7 & 0.838 \\
\hline $160-480$ & $4.413 \div 4.395$ & 8 & 0.839 & $4.423 \div 2.985$ & 8 & $0.889 \div 0.993$ \\
\hline 1200 & 4.357 & 8 & 0.842 & -0.3497 & No payback & 1.23 \\
\hline 2400 & 4.293 & 8 & 0.847 & -5.965 & No payback & 1.62 \\
\hline 4800 & 4.166 & 8 & 0.856 & -17.493 & No payback & 2.39 \\
\hline
\end{tabular}

When $\mathrm{CO}_{2}$ emission quotes of $1200 \mathrm{RUB} / \mathrm{t}(15 \mathrm{EUR} / \mathrm{t} \mathrm{CO}$ ), which correspond to the current EU level, are implemented, the oxy-fuel facility projects will become finan- 
cially efficient. In these conditions, the construction of combined cycle facilities would be detrimental.

Oxy-fuel facility projects are financially profitable with a wide range of the $\mathrm{CO}_{2}$ emission quote prices because their application in TPPs allows minimal greenhouse gas emissions.

\section{Conclusions}

Despite the remarkable efforts in the development of renewable power sources, the main power production facilities in advanced industrial countries are still traditional hydrocarbon-firing TPPs, and their number is constantly increasing. Therefore, in these countries, the main efforts for environmental safety should be directed towards mitigation of greenhouse gas emissions in traditional power generation objects.

Oxy-fuel combustion is a prospective technology for $\mathrm{CO}_{2}$ emission mitigation because of its high efficiency, environmental safety and relatively low capital investment for environmentally safe facilities. This technology is based on fuel combustion in a pure oxygen environment. The combustion product is a gas mixture enriched with carbon dioxide that is ready for water vapor removal and further sequestering.

The highly efficient Allam oxy-fuel cycle has net efficiency above $50 \%$ and low atmospheric carbon dioxide emissions of $4 \mathrm{~g} / \mathrm{kWh}$. It is clear that the financial performance of this technology can be determined by the thermodynamic parameters, initial temperature, initial pressure and carbon dioxide turbine exhaust pressure.

The main results of this study that are essential for the development of a theory of techno-economic analysis of oxygen fuel combustion power cycles are:

- A simulation model for optimizing the thermodynamic parameters of oxy-fuel facilities rated to the minimum power production prime cost and minimal capital investment criteria was proposed;

- A method for comparative analysis of the financial efficiency of buildup projects of oxy-fuel and combined cycle facilities of comparable capacities. taking into account quotas for greenhouse gas emissions, was developed.

The practical results of the study include:

- Optimization of the thermodynamic parameters of an oxy-fuel facility was carried out from the standpoint of the criterion of the minimum cost of electricity production and capital investments. At an initial temperature of $1500{ }^{\circ} \mathrm{C}$, initial pressure of $30 \mathrm{MPa}$ and turbine exhaust pressure of $2 \mathrm{MPa}$, a $414 \mathrm{MW}$ power facility has an electricity primary cost of $0.84 \mathrm{RUB} / \mathrm{kWh}$ and an installed power specific price of 36.354 thousand $\mathrm{RUB} / \mathrm{kW}$;

- A comparative analysis of the financial efficiency of buildup projects of oxy-fuel and combined cycle facilities was carried out. Without emission quotes, combined cycle facilities have a $16 \%$ higher NPV and a shorter DPP. The greater attractiveness of combined cycle facilities is due to their smaller capital investments. The primary cost values of electricity production in oxy-fuel and combined cycle facilities are compatible, which shows the similarity in the technologies' efficiency and the related similar fuel expenses;

- It was shown that when trading in carbon dioxide emission quotes is implemented, oxy-fuel facilities will actualize their environmental advantages and become more investment-attractive than the combined cycle ones. When Russia implements the $\mathrm{CO}_{2}$ emission quote of $1200 \mathrm{RUB} / \mathrm{t}$, which corresponds to the current EU level, oxy-fuel facility construction will be financially reasonable.

It is possible to conclude that oxy-fuel facilities are environmentally safe, efficient and competitive power production technologies that solve the problem of greenhouse gas emissions and provide the possibility of the stable development of the power industry. Furthermore, the financial performance of oxy-fuel facilities in terms of carbon dioxide emission quotes is similar to the performance of combined cycle facilities, which are the best alternative technology. This is caused by the high oxy-fuel equipment efficiency, the 
compactness of the equipment operating on supercritical carbon dioxide and the absence of steam turbine compartments. When carbon dioxide emission payments at the EU level are implemented, oxy-fuel facilities will become the most investment-attractive option among low-emission facilities.

The managerial consequences of the widespread application of oxygen fuel power facilities will be the stabilization of greenhouse gas emissions while ensuring the financial stability of the large industrialized countries' energy sectors.

Author Contributions: Conceptualization, A.R.; methodology, A.R., E.L. and V.K.; software, V.K. and S.O.; validation, V.K. and E.L.; formal analysis, O.Z.; investigation, V.K. and S.O.; resources, O.Z.; data curation, E.L. and S.O.; writing (original draft preparation), E.L.; writing (review and editing), A.R. and O.Z.; visualization, S.O.; supervision, A.R.; project administration, A.R.; funding acquisition, O.Z. All authors have read and agreed to the published version of the manuscript.

Funding: This study conducted by the Moscow Power Engineering Institute was financially supported by the Ministry of Science and Higher Education of the Russian Federation (project no. FSWF-2020-0020).

Institutional Review Board Statement: Not applicable.

Informed Consent Statement: Not applicable.

Data Availability Statement: Not applicable.

Conflicts of Interest: The authors declare no conflict of interest.

\section{Nomenclature}

\section{A List of Symbols}

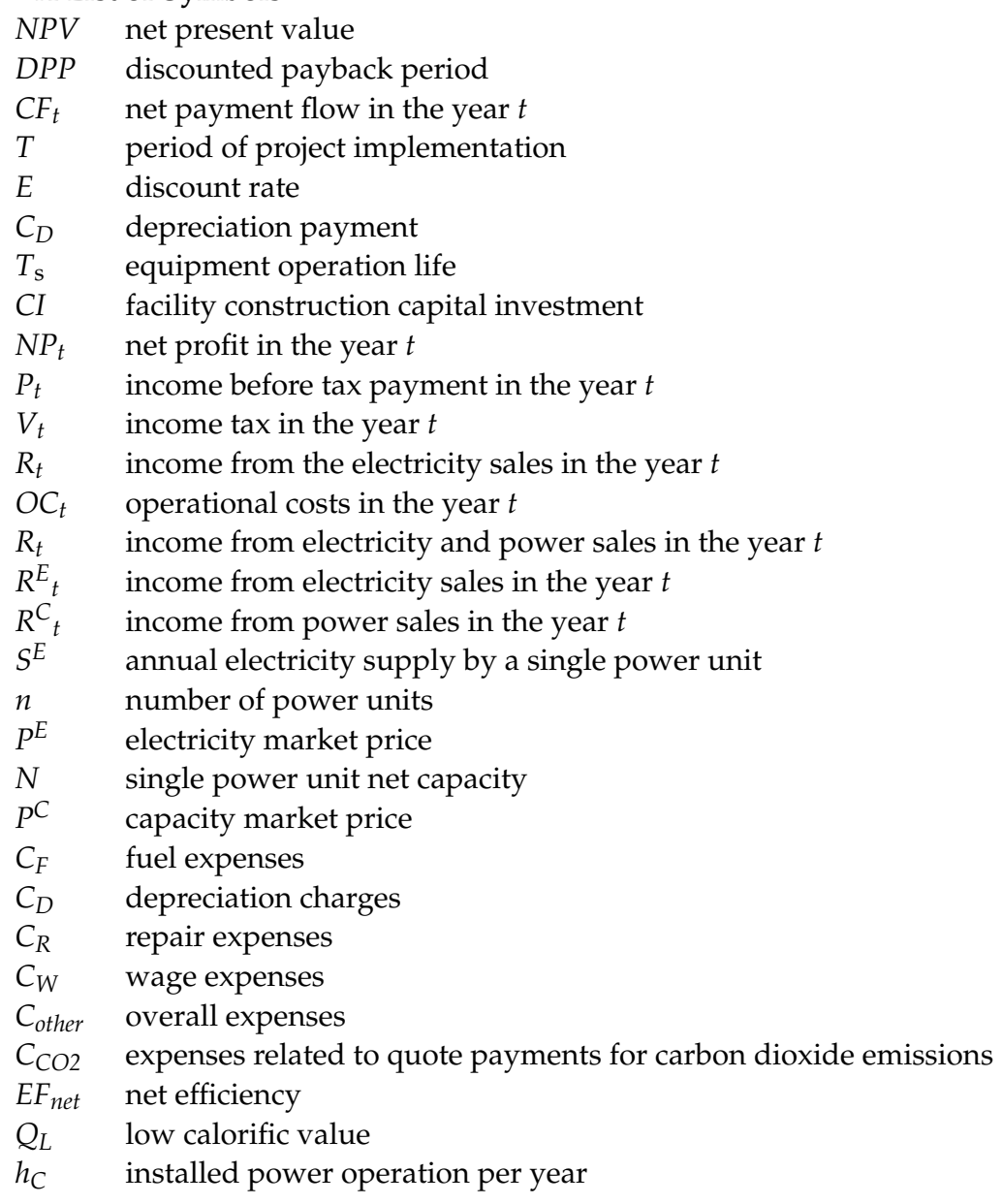




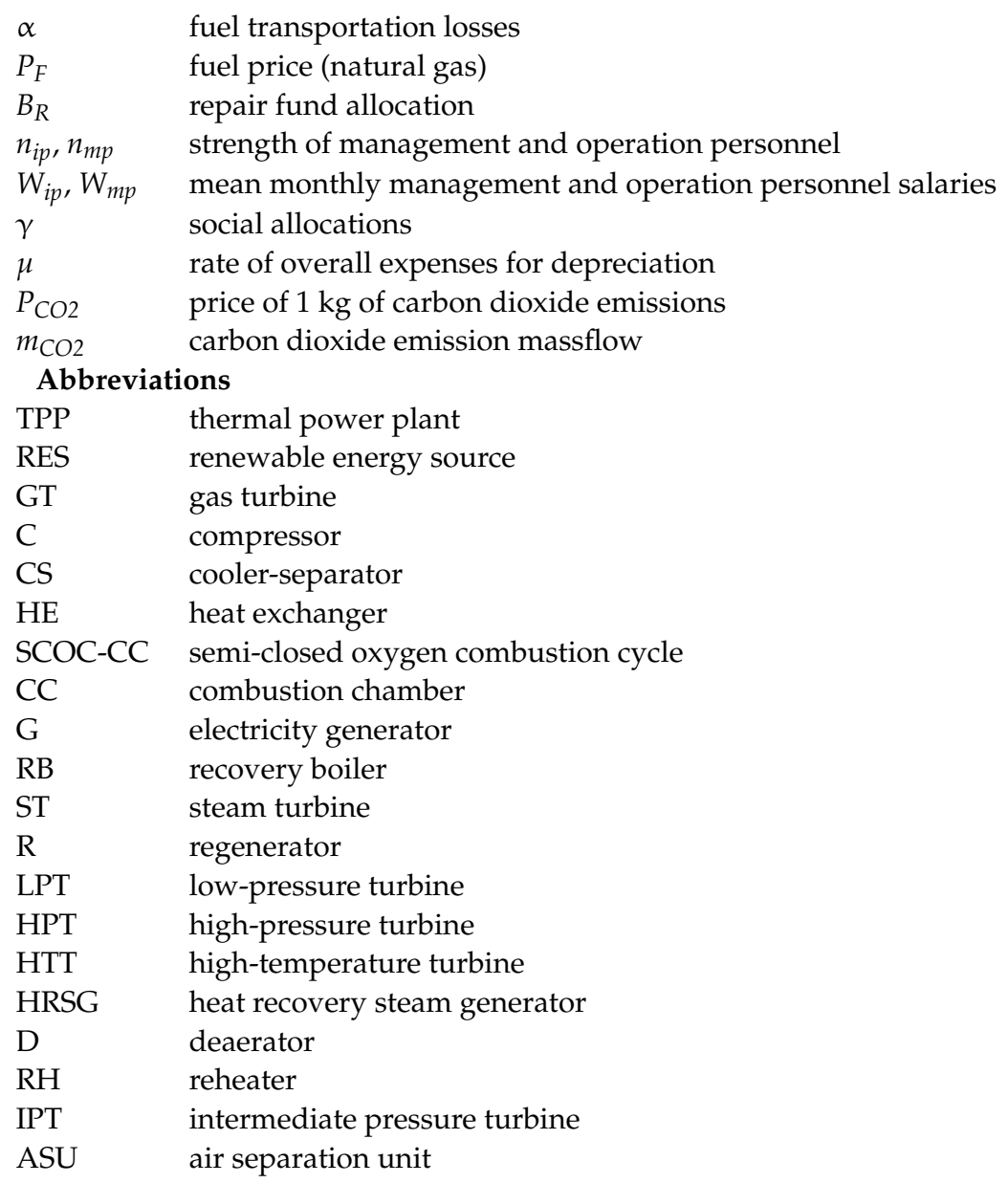

\section{References}

1. Rahmstorf, S.; Cazenave, A.; Church, J.A.; Hansen, J.E.; Keeling, R.F.; Parker, D.E.; Somerville, R.C. Recent climate observations compared to projections. Science 2007, 316, 709. [CrossRef] [PubMed]

2. Lal, R.; Delgado, J.A.; Groffman, P.M.; Millar, N.; Dell, C.; Rotz, A. Management to mitigate and adapt to climate change. J. Soil Water Conserv. 2011, 66, 276-282. [CrossRef]

3. Arrhenius, S. On the influence of carbonic acid in the air upon the temperature of the ground. Lond. Edinb. Dublin Philos. Mag. J. Sci. 1896, 41, 237-276. [CrossRef]

4. Ritchie, H.; Roser, M. $\mathrm{CO}_{2}$ Emissions-Our World in Data. Available online: https:/ / ourworldindata.org/co2-emissions (accessed on 15 June 2021).

5. Emissions Database for Global Atmospheric Research-2019 Report. Publications Office of the European Union. 2019. Available online: https:/ / edgar.jrc.ec.europa.eu/ (accessed on 15 June 2021).

6. McNeill, J.R. Something New under the Sun: An Environmental History of the Twentieth-Century World; The Global Century Series; WW Norton \& Company: London, UK, 2001; 448p.

7. Houghton, J.T.; Ding, Y.D.; Griggs, D.J.; Noguer, M.; van der Linden, P.J.; Dai, X.; Johnson, C.A. Climate Change 2001: The Scientific Basis; The Press Syndicate of the University of Cambridge: Cambridge, UK, 2001; 881p.

8. Lockwood, M.; Fröhlich, C. Recent oppositely directed trends in solar climate forcings and the global mean surface air temperature. Proc. R. Soc. Lond. A Math. Phys. Eng. Sci. 2007, 463, 2447-2460. [CrossRef]

9. Verheggen, B. Recent Changes in the Sun, $\mathrm{CO}_{2}$ and Global Average Temperature. Available online: https://ourchangingclimate. wordpress.com (accessed on 15 June 2021).

10. Davis, S.J.; Caldeira, K. Consumption-based accounting of $\mathrm{CO}_{2}$ emissions. Proc. Natl. Acad. Sci. USA 2010, 107, 5687-5692. [CrossRef]

11. Nejat, P.; Jomehzadeh, F.; Taheri, M.M.; Gohari, M.; Majid, M.Z. A global review of energy consumption, $\mathrm{CO}_{2}$ emissions and policy in the residential sector (with an overview of the top ten $\mathrm{CO}_{2}$ emitting countries). Renew. Sustain. Energy Rev. 2015, 43, 843-862. [CrossRef]

12. Hoffert, M.I.; Covey, C. Deriving global climate sensitivity from palaeoclimate reconstructions. Nature 1992, 360, 573-576. [CrossRef]

13. Lisin, E.; Strielkowski, W.; Krivokora, E. Economic Analysis of Industrial Development: A Case of Russian Coal Industry. Montenegrin J. Econ. 2016, 12, 129-139. [CrossRef] 
14. Lisin, E.; Rogalev, A.; Strielkowski, W.; Komarov, I. Sustainable modernization of the Russian power utilities industry. Sustainability 2015, 7, 11378-11400. [CrossRef]

15. Lisin, E.; Sobolev, A.; Strielkowski, W.; Garanin, I. Thermal efficiency of cogeneration units with multi-stage reheating for Russian municipal heating systems. Energies 2016, 9, 269. [CrossRef]

16. Tvaronavičienè, M.; Lisin, E.; Kindra, V. Power market formation for clean energy production as the prerequisite for the country's energy security. Energies 2020, 13, 4930. [CrossRef]

17. Lisin, E.; Kurdiukova, G.; Okley, P.; Chernova, V. Efficient Methods of Market Pricing in Power Industry within the Context of System Integration of Renewable Energy Sources. Energies 2019, 12, 3250. [CrossRef]

18. Oh, S.Y.; Yun, S.; Kim, J.K. Process integration and design for maximizing energy efficiency of a coal-fired power plant integrated with amine-based $\mathrm{CO}_{2}$ capture process. Appl. Energy 2018, 216, 311-322. [CrossRef]

19. Campbell, R.J. Increasing the Efficiency of Existing Coal-Fired Power Plants. CRS Report. 2013, 30p. Available online: www.crs. gov (accessed on 15 June 2021).

20. Marchal, V.; Dellik, R. OECD Environmental Outlook to 2050; Organization for Economic Co-operation and Development: Paris, France, 2011; 91p.

21. Tcvetkov, P.; Cherepovitsyn, A.; Fedoseev, S. The changing role of $\mathrm{CO}_{2}$ in the transition to a circular economy: Review of carbon sequestration projects. Sustainability 2019, 11, 5834. [CrossRef]

22. Rahman, F.A.; Aziz, M.A.; Saidur, R.; Bakar, W.A.; Hainin, M.R.; Putrajaya, R.; Hassan, N.A. Pollution to solution: Capture and sequestration of carbon dioxide $\left(\mathrm{CO}_{2}\right)$ and its utilization as a renewable energy source for a sustainable future. Renew. Sustain. Energy Rev. 2017, 71, 112-126. [CrossRef]

23. Feng, K.; Davis, S.J.; Sun, L.; Hubacek, K. Drivers of the US $\mathrm{CO}_{2}$ emissions 1997-2013. Nat. Commun. 2015, 6, 1-8. [CrossRef]

24. Kelemen, P.; Benson, S.M.; Pilorgé, H.; Psarras, P.; Wilcox, J. An overview of the status and challenges of $\mathrm{CO}_{2}$ storage in minerals and geological formations. Front. Clim. 2019, 1, 9. [CrossRef]

25. Kearns, J.; Teletzke, G.; Palmer, J.; Thomann, H.; Kheshgi, H.; Chen, Y.H.; Herzog, H. Developing a consistent database for regional geologic CO2 storage capacity worldwide. Energy Procedia 2017, 114, 4697-4709. [CrossRef]

26. Lecomte, F.; Broutin, P.; Lebas, E. $\mathrm{CO}_{2}$ Capture: Technologies to Reduce Greenhouse Gas Emissions; Editions Technip: Paris, France, 2010; 98p.

27. Kanniche, M.; Le Moullec, Y.; Authier, O.; Hagi, H.; Bontemps, D.; Neveux, T.; Louis-Louisy, M. Up-to-date CO 2 capture in thermal power plants. Energy Procedia 2017, 114, 95-103. [CrossRef]

28. Wang, Y.; Zhao, L.; Otto, A.; Robinius, M.; Stolten, D. A review of post-combustion $\mathrm{CO}_{2}$ capture technologies from coal-fired power plants. Energy Procedia 2017, 114, 650-665. [CrossRef]

29. Mukherjee, S.; Kumar, P.; Yang, A.; Fennell, P. Energy and exergy analysis of chemical looping combustion technology and comparison with pre-combustion and oxy-fuel combustion technologies for $\mathrm{CO}_{2}$ capture. J. Environ. Chem. Eng. 2015, 3, 2104-2114. [CrossRef]

30. Allam, R.; Martin, S.; Forrest, B.; Fetvedt, J.; Lu, X.; Freed, D.; Manning, J. Demonstration of the Allam Cycle: An update on the development status of a high efficiency supercritical carbon dioxide power process employing full carbon capture. Energy Procedia 2017, 114, 5948-5966. [CrossRef]

31. Rogalev, A.; Grigoriev, E.; Kindra, V.; Rogalev, N. Thermodynamic optimization and equipment development for a high efficient fossil fuel power plant with zero emissions. J. Clean. Prod. 2019, 236, 117592. [CrossRef]

32. Cau, G.; Tola, V.; Ferrara, F.; Porcu, A.; Pettinau, A. $\mathrm{CO}_{2}$-free coal-fired power generation by partial oxy-fuel and post-combustion $\mathrm{CO}_{2}$ capture: Techno-economic analysis. Fuel 2018, 214, 423-435. [CrossRef]

33. Rogalev, A.; Rogalev, N.; Kindra, V.; Zlyvko, O.; Vegera, A. A Study of Low-Potential Heat Utilization Methods for Oxy-Fuel Combustion Power Cycles. Energies 2021, 14, 3364. [CrossRef]

34. Barba, F.C.; Sanchez, G.M.D.; Segui, B.S.; Darabkhani, H.G.; Anthony, E.J. A technical evaluation, performance analysis and risk assessment of multiple novel oxy-turbine power cycles with complete $\mathrm{CO}_{2}$ capture. J. Clean. Prod. 2016, 133, 971-985. [CrossRef]

35. Kindra, V.O.; Kaplanovich, I.B.; Smirnov, M.V.; Naumov, V.Y.; Zonov, A.S. Parametric optimization of the semi-closed oxy-fuel combustion combined cycle. J. Phys. Conf. Ser. 2020, 1683, 052028. [CrossRef]

36. Zhao, Y.; Chi, J.; Zhang, S.; Xiao, Y. Thermodynamic study of an improved MATIANT cycle with stream split and recompression. Appl. Therm. Eng. 2017, 125, 452-469. [CrossRef]

37. Rogalev, N.D.; Petrenya, Y.K.; Kindra, V.O.; Rogalev, A.N. Oxy-fuel power cycles promoting the transition to green and sustainable future in the energy sector. In Sustainable Fuel Technologies Handbook; Academic Press: Cambridge, MA, USA, 2021 ; pp. 513-539.

38. Wimmer, K.; Sanz, W. Optimization and comparison of the two promising oxy-combustion cycles NET Power cycle and Graz Cycle. Int. J. Greenh. Gas Control 2020, 99, 103055. [CrossRef]

39. Yang, H.J.; Kang, D.W.; Ahn, J.H.; Kim, T.S. Evaluation of design performance of the semi-closed oxy-fuel combustion combined cycle. J. Eng. Gas Turbines Power 2012, 134, 111702. [CrossRef]

40. Mathieu, P.; Dubuisson, R.; Houyou, S.; Nihart, R. New concept of $\mathrm{CO}_{2}$ removal technologies in power generation, combined with fossil fuel recovery and long term $\mathrm{CO}_{2}$ sequestration. Proc. ASME Turbo Expo 2000, 78552, V002T04A011.

41. Crespi, F.; Gavagnin, G.; Sánchez, D.; Martínez, G.S. Analysis of the thermodynamic potential of supercritical carbon dioxide cycles: A systematic approach. J. Eng. Gas Turbines Power 2018, 140, 051701. [CrossRef] 
42. Jericha, H.; Sanz, W.; Göttlich, E. Design concept for large output Graz cycle gas turbines. J. Eng. Gas Turbines Power 2008, 130, 011701. [CrossRef]

43. Sanz, W.; Braun, M.; Jericha, H.; Platzer, M.F. Adapting the zero-emission Graz Cycle for hydrogen combustion and investigation of its part load behavior. Int. J. Hydrogen Energy 2018, 43, 5737-5746. [CrossRef]

44. Abbas, F.; Hammad, H.M.; Fahad, S.; Cerdà, A.; Rizwan, M.; Farhad, W.; Bakhat, H.F. Agroforestry: A sustainable environmental practice for carbon sequestration under the climate change scenarios-A review. Environ. Sci. Pollut. Res. 2017, 24, 11177-11191. [CrossRef] [PubMed]

45. Kvamsdal, H.M.; Jordal, K.; Bolland, O. A quantitative comparison of gas turbine cycles with $\mathrm{CO}_{2}$ capture. Energy 2007, 32, 10-24. [CrossRef]

46. Allam, R.J.; Palmer, M.; Brown, G.W. System and Method for High Efficiency Power Generation Using a Carbon Dioxide Circulating Working Fluid. U.S. Patent 8596075 B2, 3 December 2013.

47. Rogalev, A.; Kindra, V.; Osipov, S. Modeling methods for oxy-fuel combustion cycles with multicomponent working fluid. AIP Conf. Proc. 2018, 2047, 020020.

48. Rogalev, A.; Kindra, V.; Osipov, S.; Rogalev, N. Thermodynamic analysis of the net power oxy-combustion cycle. In 13th European Conference on Turbomachinery Fluid Dynamics \& Thermodynamics; ETC2019-030; European Turbomachinery Society: Florence, Italy, 2019. [CrossRef]

49. Choi, B.S.; Kim, M.J.; Ahn, J.H.; Kim, T.S. Influence of a recuperator on the performance of the semi-closed oxy-fuel combustion combined cycle. Appl. Therm. Eng. 2017, 124, 1301-1311. [CrossRef]

50. Kurbatova, S.; Aisner, L.; Rusakov, A.; Naumkina, V. Ecological postulates of the national environmental policy (on the example of the Russian Federation). In E3S Web of Conferences; EDP Sciences: Paris, France, 2020; Volume 157, p. 04023.

51. Fedorov, M.P.; Elistratov, V.V.; Maslikov, V.I.; Sidorenko, G.I.; Chusov, A.N.; Atrashenok, V.P.; Zinchenko, A.V. Reservoir greenhouse gas emissions at Russian TPP. Power Technol. Eng. 2015, 49, 33-39. [CrossRef]

52. Liubarskaia, M.A.; Merkusheva, V.S.; Zinovieva, O.S. Participation of Russia in the International Cooperation for Reducing Greenhouse Gas Emissions by Energy Companies. Vestn. RUDN Int. Relat. 2019, 19, 377-391. [CrossRef]

53. Lyapina, I.R.; Skobliakova, I.V.; Vlasova, M.A.; Lukyanchikova, T.L.; Kononova, E.E. Ecological innovations in Russia: Peculiarities and mechanisms of realization. In Perspectives on the Use of New Information and Communication Technology (ICT) in the Modern Economy; Springer: Berlin/Heidelberg, Germany, 2017; pp. 748-757. 